Review

\title{
Emergent food proteins - Towards sustainability, health and innovation
}

\author{
L.H. Fasolin ${ }^{a, b}$, R.N. Pereira ${ }^{a}$, A.C. Pinheiro ${ }^{a}$, J.T. Martins ${ }^{a}$, C.C.P. Andrade ${ }^{a}$, O.L. Ramos ${ }^{c}$, \\ A.A. Vicente ${ }^{\mathrm{a}, *}$ \\ ${ }^{a}$ Centre of Biological Engineering, University of Minho, Campus de Gualtar, 4710-057 Braga, Portugal \\ ${ }^{\mathrm{b}}$ Department of Food Engineering, School of Food Engineering, University of Campinas - UNICAMP, 13083-862 Campinas, SP, Brazil \\ c Universidade Católica Portuguesa, CBQF - Centro de Biotecnologia e Química Fina - Laboratório Associado, Escola Superior de Biotecnologia, Rua Diogo Botelho 1327, \\ 4169-005 Porto, Portugal
}

\section{A R T I C L E I N F O}

\section{Keywords:}

Novel proteins

Green process

Structure

Digestibility

Allergenicity

\begin{abstract}
A B S T R A C T
There is an increasing demand for alternative and sustainable protein sources, such as vegetables, insects and microorganisms, that can meet the nutritional and sensory pleasantness needs of consumers. This emergent interest for novel protein sources, allied with "green" and cost-effective processing technologies, such as high hydrostatic pressure, ohmic heating and pulsed electric fields, can be used as strategies to improve the consumption of proteins from sustainable sources without compromising food security. In addition to their nutritional value, these novel proteins present several technological-functional properties that can be used to create various protein systems in different scales (i.e., macro, micro and nano scale), which can be tailored for a specific application in innovative food products.

However, in order for these novel protein sources to be broadly used in future food products, their fate in the human gastrointestinal tract (e.g., digestion and bioavailability) must be assessed, as well as their safety for consumers must be clearly demonstrated. In particular, these proteins may become novel allergens triggering adverse reactions and, therefore, a comprehensive allergenicity risk assessment is needed.

This review presents an overview of the most promising alternative protein sources, their application in the production of innovative food systems, as well as their potential effects on human health. In addition, new insights on sustainable processing strategies are given.
\end{abstract}

\section{Introduction}

Currently, a significant number of trends at planetary scale are compromising the sustainability of food and agricultural systems, and the main reason for this can be explained by global population increase. The world's population is now more than 7.7 billion persons, and this number is presently growing at a rate of around $1.07 \%$ per year, which is expected to reach the 10 billion mark by 2050 ( $>30 \%$ of current population) (Worldometers, 2019). This will inevitably mean agricultural expansion and productivity growth, which in turn will overpressure natural resources by increasing deforestation, greenhouse gas emissions and water consumption, thus contributing to world's ecological insufficiency and climate changes (FAO, 2017). For example, from 2010 to 2050 it is projected that meat and dairy products world consumption will increase about $173 \%$ and $158 \%$, respectively (FAO, 2011). This continued expansion of food production and increasing demand for animal protein is causing serious concerns. The resources needed to convert vegetable matter into animal-derived proteins like meat or milk proteins are inefficient by $7: 1-$ i.e. $7 \mathrm{~kg}$ of vegetable food is required to produce $1 \mathrm{~kg}$ of milk or meat for human consumption (Nadathur, Wanasundara, \& Scanlin, 2017). Since April 2016, the United Nations Decade of Action on Nutrition is ongoing with main objective "to eliminate malnutrition in all its forms", but also to develop "sustainable, resilient food systems for healthy diets" following the framework agreed at Second International Conference on Nutrition in 2014 (FAO, 2014). For this reason, much has been discussed not only about food alternatives, but also about all the dimensions that integrate the concept of food safety and sustainability.

It is then necessary to adopt a more sustainable production of the conventionally used proteins and to start rebalance the contributions between animal and plant proteins (or other alternatives), thus contributing to the sustainability of food systems, biodiversity and eventually, to a more efficient distribution of high quality proteins for the entire world population (Aiking \& de Boer, 2018; Chardigny \& Walrand, 2016; Henchion, Hayes, Mullen, Fenelon, \& Tiwari, 2017). The global context, the pressure of government and non-governmental policies,

\footnotetext{
* Corresponding author.

E-mail address: avicente@deb.uminho.pt (A.A. Vicente).
} 
along with the current intention of consumers to include more plantbased proteins in their daily diets (Niva, Vainio, \& Jallinoja, 2017), are bringing to discussion the importance of a greater knowledge about the use of alternative protein sources and their impact on human health. Some examples of considered emergent and sustainable protein sources include grains (e.g., wheat and zein), seeds (e.g., chia), leaves (e.g., moringa), pulses (e.g., beans, lentils, peas), microalgae, fungi (e.g., mycoproteins), milk (e.g., whey proteins) and insects.

In a context where not only socioeconomic, environmental, but also, health dimensions are increasingly intertwined with food production systems and food consumer perception, the impact that these emergent protein sources bring to health and wellbeing upon consumption should be thoroughly discussed. The use of encapsulated biomolecules is now considered as an important innovative trend (De Vries et al., 2018). Vegetable and animal protein-rich fractions due to their functional and technological properties - i.e., ability to interact with biomolecules to form gels, hydrogels or emulsions - can be designed as delivery systems (at nano or micro-scale) to protect and deliver bioactive compounds with intended functionalities at specific sites in the human body. An outstanding example of this versatility is the case of whey serum from milk, recently considered as dairy waste, it is now used as rich-protein fraction with interesting properties regarding nutritional value (e.g., balanced amino acid profile), functionality (e.g., enhanced digestibility, gelation, foaming and emulsifying capacities) and bioactivity (e.g., antimicrobial, antiviral and anti-carcinogenic) (Ramos et al., 2017). Among the various unit operations in the food industry, processing such as heating and enzymatic treatments are probably the ones that most affect proteins, thus influencing the outcomes of the gastrointestinal digestion process and consequent sensitization of the immune system. Fundamental research is still needed to achieve a comprehensive understanding of the biochemical function of emergent food proteins and adequacy of sustainable processing strategies for a better maintenance of nutritional profile and reduced risk of allergenicity.

Today, food production needs to evolve to sustainable exploitation of natural resources and at the same time, meet the growing demand for a balanced diet focused on healthier products (van der Goot et al., 2016; Vos \& Bellù, 2019). Recently, De Vries et al. (2018) highlighted the importance of three main innovation directions for the future food systems: 1) better efficiency - "mass production at the lowest possible price"; 2) innovation opportunity driven by consumer trends and the need to balance the use animal-origin proteins - development of new perceptions/sensations and niche products with high value at small scale; and 3) development of functional foods targeting health and wellbeing upon consumption. The use of alternative protein sources allied to the use of eco-innovative and cost-effective technologies is then aligned with this paradigm shift.

This review intends to address the most promising alternative protein sources, while providing new insights on sustainable processing strategies that can bring innovation and added value for underrated protein rich fractions. The potential health-related implications upon consumption will be also critically discussed.

\section{Sustainable aspects of alternative proteins sources}

Nutrition is the main function of foods, and good nutrition is a dimension of food security and sustainability. However, as summarized in Fig. 1, assessing social and environmental aspects and economic costs of emergent foods is important for evaluating their long-term sustainability. According to FAO definition (FAO, 2010), sustainable food systems are those that deliver food security and nutrition for all in a way that economic, social and environmental sustainability is not compromised for future generations. In this way, this section will address sustainability aspects of some emerging proteins.

\subsection{Vegetable proteins}

When thinking about replacing conventional proteins (e.g., meat and egg proteins), vegetable sources seem to be a natural substitute, since they are naturally present in people's diets, bring health and environmental benefits and have lower production associated costs. Plantbased foods have lower greenhouse gas emissions and tend to be less resource-intensive and environmentally destructive than animal husbandry. In addition, vegetable proteins reduce the risk of spreading diseases such as bovine spongiform encephalitis (Elzoghby, Samy, \& Elgindy, 2012; Tarhini, Greige-Gerges, \& Elaissari, 2017). For such reason, encouragement of partial replacement of proteins from animal husbandry by vegetable-based ones could have a positive impact on decreasing climate changes and biodiversity loss (Joyce, Dixon, Comfort, \& Hallett, 2012; Stoll-Kleemann \& Schmidt, 2017). On the other hand, agriculture still has a negative impact as a result of decreasing soil fertility levels, polluting water resources with agrochemicals and contributing to deforestation and desertification due to the high demand of cropland areas (Gahukar, 2016). However, in a general way, plant protein utilization can reduce the demand for animal protein sources and consequently their environmental impact (Tian, Bryksa, \& Yada, 2016).

Concerning nutritional aspects, different foods such as seeds, legumes, nuts, fruits and vegetables can be not only alternative protein sources but also, provide numerous health promoting nutrients such as vitamins, minerals, fibers, antioxidants and anti-inflammatory agents that are important in healthy diets (Kojima et al., 2018; Msambichaka et al., 2018). Despite of the high protein content of some vegetable sources (Table 1), it is known that conventional animal proteins have a high quality, while vegetable proteins are generally deficient in essential amino acids (Lonnie et al., 2018). However, the essential amino acids content is not the only factor to classify the nutritional quality of proteins. Digestibility and bioavailability also affect their utilization and must be considered (Lynch, Johnston, \& Wharton, 2018). Combining plant sources in the right balance is a good solution to achieve adequate essential amino acid profiles, and such diet is supported and promoted by the Academy of Nutrition and Dietetics (Melina, Craig, \& Levin, 2016).

Moreover, it has been well documented that a partial exchange of animal for vegetable protein sources is related to beneficial effects on gut microbiota, and reduced risk of type 2 diabetes, cardiovascular diseases and of other mortality causes (Busnelli, Manzini, Sirtori, Chiesa, \& Parolini, 2018; Malik, Li, Tobias, Pan, \& Hu, 2016; Song et al., 2016; Tharrey et al., 2018). For these reasons, in the last decade, the number of works unraveling the nutritional and technological functionality of vegetable protein increased exponentially.

Vegetable proteins can be divided into albumins, globulins, prolamins and glutelins that possess different technological properties (Day, 2013). Rapeseed shows great foam and emulsion-stabilizing properties due to the presence of cruciferin and napin. Proteins from legumes (e.g., lupin, chickpea, lentil and pea) and nuts (e.g., cashew nut) possess strong potential for stabilization of emulsions and foams, and/or gel formation (Berghout, Boom, \& van der Goot, 2015; Burgos-Díaz et al., 2018; Djoullah, Husson, \& Saurel, 2018; Ladjal Ettoumi, Chibane, \& Romero, 2016; Liu et al., 2018; Tabilo-Munizaga et al., 2019). Soybean protein presents gelling properties but also phenolic compounds that may reduce the nutritional and functional quality. However, soy protein gels' elasticity increases when phenolic compounds are removed (Alu'datt, Rababah, \& Alli, 2014). Furthermore, food industrial vegetable-based by-products have been used for protein isolation, such as apple pomace, oat bran, sugar beet leaves and orange pulp (HucMathis, Journet, Fayolle, \& Bosc, 2019; Tamayo Tenorio, Gieteling, Nikiforidis, Boom, \& van der Goot, 2017; Wallecan, McCrae, Debon, Dong, \& Mazoyer, 2015). 


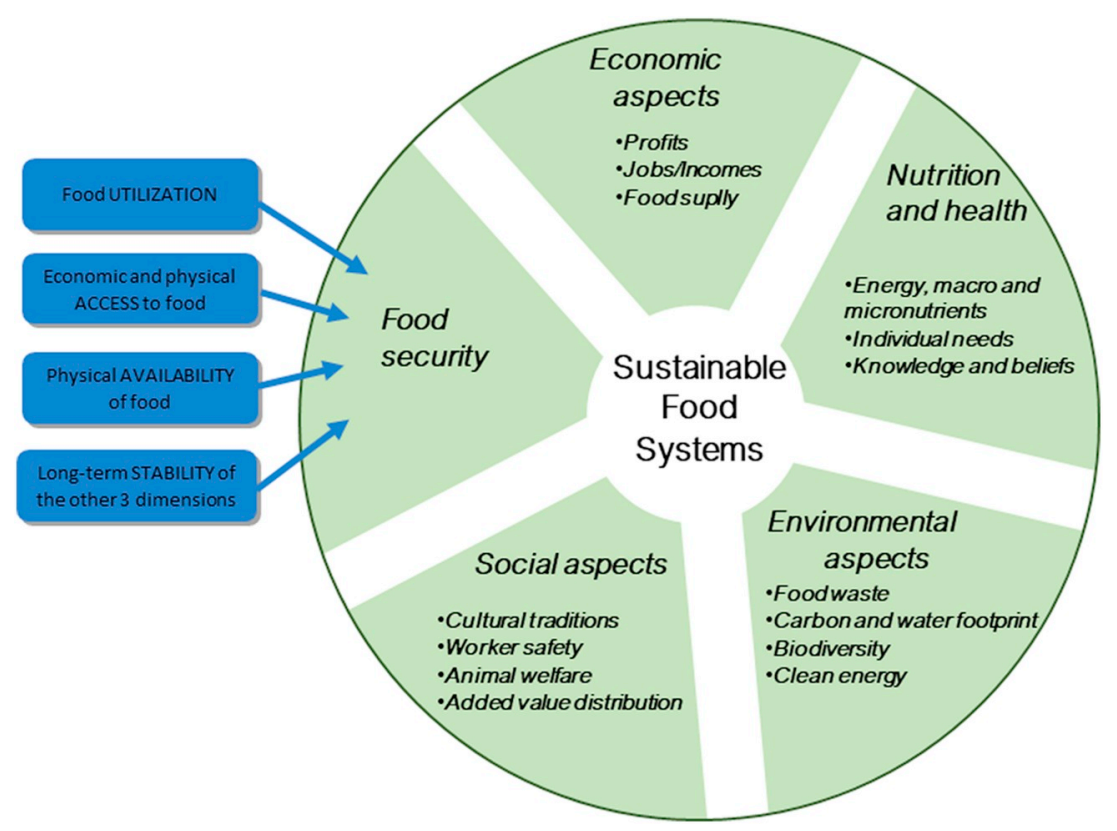

Fig. 1. Schematic framework of food safety and sustainable food systems dimensions.

\subsection{Insect proteins}

Insects are probably one of the most controversial alternative to animal protein source because it conflicts with cultural habits in some populations Although their consumption is widespread in Eastern, African and some Latin American countries, with over 2000 species classified as edible (Jongema, 2017), their introduction on Western eating habits is not well accepted and there are some issues that must be overcome (Hartmann \& Siegrist, 2016; Piha, Pohjanheimo, Lähteenmäki-Uutela, Křečková, \& Otterbring, 2018). Most consumers still not associate insects to food, instead they relate potential consumption as a primitive and disgusting behavior (Lensvelt \& Steenbekkers, 2014; Woolf, Zhu, Emory, Zhao, \& Liu, 2019). On the other hand, the use of processed insects as powder ingredient has been an alternative that could enhance consumers' acceptance (Hartmann \& Siegrist, 2016; Piha et al., 2018). Their use in pastas, tortilla chips and breads has been assessed in terms of nutritional value and structural and sensory features (Duda, Adamczak, Chełmińska, Juszkiewicz, \& Kowalczewski, 2019; Hartmann \& Siegrist, 2016; Osimani et al., 2018; Roncolini et al., 2019). Nevertheless, insects are considered a sustainable food system, once besides their nutritional value, insect breeding has also positive ecological, environmental and economic impacts (de Castro, Ohara, dos Santos Aguilar, \& Domingues, 2018; SunWaterhouse et al., 2016). Among the groups generally consumed there are Coleoptera $(31 \%)$, Lepidoptera $(18 \%)$, Hymenoptera $(14 \%)$, Orthoptera (13\%) and Hemiptera (10\%) (Sun-Waterhouse et al., 2016).

There are several advantages when comparing insect farming with traditional agriculture and animal husbandry. For example, it has less impact on deforestation and soil fertility reduction since they have a smaller land-use footprint with low environmental contamination (Oonincx, 2017). Cultivating them also requires less water consumption, using up to $50 \%$ less in some cases (Miglietta, De Leo, Ruberti, \&

Table 1

Examples of alternative protein sources and their protein content.

\begin{tabular}{|c|c|c|c|}
\hline Source & Name & Protein content $(\%, w / w)$ & Reference \\
\hline \multirow[t]{4}{*}{ Vegetable } & Amaranth (Amaranthus spp.) & $12.5-17.6$ & Caselato-Sousa \& Amaya-Farfán, 2012 \\
\hline & Lupin (Lupinus spp.) & $38-55$ & Bähr, Fechner, Hasenkopf, Mittermaier, \& Jahreis, 2014 \\
\hline & Navy bean (Phaseolus vulgaris) & 26.0 & Tabtabaei, Konakbayeva, Rajabzadeh, \& Legge, 2019 \\
\hline & Quinoa (Chenopodium quinoa Willd) & $12-23$ & Ruiz, Xiao, van Boekel, Minor, \& Stieger, 2016 \\
\hline \multirow[t]{6}{*}{ Algae } & Aphanothece microscopica & 42 & Zepka, Jacob-Lopes, Goldbeck, Souza-Soares, \& Queiroz, 2010 \\
\hline & Arthrospira platensis (Spirulina platensis) & 53.5 & Benelhadj et al., 2016; Chronakis, Galatanu, Nylander, \& Lindman, 2000; Safi et al., 2014 \\
\hline & Chlorella vulgaris & $12.7-53.0$ & Laurens et al., 2017; Ursu et al., 2014 \\
\hline & Dunaliella salina & $51.2-82.2$ & Sui, Muys, Vermeir, D'Adamo, \& Vlaeminck, 2019 \\
\hline & Haematococcus pluvialis & $30-51.7$ & Ba et al., 2016; Safi et al., 2014 \\
\hline & Tetraselmis sp & 36 & Schwenzfeier, Wierenga, \& Gruppen, 2011 \\
\hline \multirow[t]{6}{*}{ Fungi } & Aspergillus niger & $10.3-61.2$ & Kamal et al., 2019 \\
\hline & Fusarium venenatum & $41.8-46.4$ & Hosseini \& Khosravi-Darani, 2011 \\
\hline & Saccharomyces cerevisiae & $15.3-49.3$ & Bacha et al., 2011; Gervasi et al., 2018 \\
\hline & Torula utilis (Candida utilis) & $28.4-48.9$ & Kurcz et al., 2018 \\
\hline & Yarrowia lipolytica & $45-55$ & Turck et al., 2019 \\
\hline & Methylococcus capsulatus & 53 & Rasouli, Valverde-Pérez, D'Este, De Francisci, \& Angelidaki, 2018 \\
\hline \multirow[t]{2}{*}{ Bacteria } & Rhodopseudomonas sp. & $54-92$ & Yang et al., 2017 \\
\hline & Rhodopseudomonas faecalis & $50-51.5$ & Saejung \& Salasook, 2018 \\
\hline \multirow[t]{4}{*}{ Insect } & Cricket (Gryllodes sigillatus) & $56.8^{\mathrm{a}}$ & Hall et al., 2017 \\
\hline & Grasshopper (Schistocerca gregaria) & 76.0 & Mishyna, Martinez, Chen, \& Benjamin, 2019 \\
\hline & Honey bee brood (Apis mellifera) & 22.1 & Mishyna, Martinez, Chen, Davidovich-Pinhas, \& Benjamin, 2019 \\
\hline & Mealworm (Tenebrio molitor) & $51.0^{\mathrm{a}}$ & Zhao et al., 2016 \\
\hline
\end{tabular}

\footnotetext{
${ }^{a}$ Protein conversion factor of 6.25 .
} 
Massari, 2015). Also, they are responsible for relatively low emissions of greenhouse gases and ammonia compared to traditionally farmed cattle, poultry, fish and seafood (Poma et al., 2017). In fact, one of the main reasons to be considered as potentially sustainable alternative protein source is their high feed conversion efficiency (van Huis, 2013), short life-cycles and high reproduction rates (Sun-Waterhouse et al., 2016). Moreover, insects can grow with a wide range of foods, including by-products from food processing and high-impacting waste streams (Smetana, Palanisamy, Mathys, \& Heinz, 2016). These aspects make insects as one of the most environmentally beneficial and economical viable crops.

Regarding their nutritional aspects, great differences can be found mainly because there is a large quantity of species. However, insects are rich in protein and fat, and can provide a certain amount of minerals and vitamins (de Castro et al., 2018). Iron, zinc, potassium, sodium, calcium, phosphorus, magnesium, manganese, copper, riboflavin, pantothenic acid, biotin and folic acid can be found in insects (de Castro et al., 2018; van Huis, 2013). Indeed, in some species, zinc and iron concentrations can be similar to beef and higher than chicken and pork (Mwangi et al., 2018). Fat represents the second largest fraction of the nutrient composition, typically between $5 \%$ and $40 \%$ of dry matter. However, its content is dependent on life stage and can reach over $70 \%$ (Roos, 2018). In addition, (Stull et al., 2018) showed evidences that cricket supplementation improved gut health and reduced systemic inflammation.

Protein content of most insects is around $60 \%$ and this value can vary between $7 \%$ and $91 \%$ (dry weight) (van Huis, 2016) and some examples are shown in Table 1 . Besides the differences among the species, other factors as development stage (Mishyna, Martinez, Chen, \& Benjamin, 2019; Roos, 2018) and sex (Kulma et al., 2019) can exert effect on protein content. In general, protein values make some insect protein content comparable to meat and also plant sources (Yi et al., 2013). However, it is worth mentioning that information regarding protein may be dubious. Most of papers use Kjeldahl standard protocol to quantify protein content, considering that all the nitrogen present is in the form of protein, using the conversion factor of 6.25 (well accepted for foods). But arthropods have an exoskeleton built primarily of chitin fibers and polysaccharides containing nitrogen atoms (Jonas-Levi \& Martinez, 2017). This exoskeleton and some fraction of insect proteins are not digestible by humans. Thus, the use of Kjeldahl method with conversion factor of 6.25 overestimates the protein content (JonasLevi \& Martinez, 2017; Mishyna, Martinez, Chen, \& Benjamin, 2019). Indeed, Janssen, Vincken, van den Broek, Fogliano, and Lakemond (2017) estimated lower values for Tenebrio molitor, Alphitobius diaperinus, and Hermetia illucens. In addition, Mishyna, Martinez, Chen, and Benjamin (2019) showed that the development stages also exert influence, estimating a nitrogen-to-protein conversion factors of 4.5 for adult grasshopper, and 4.9 and 5.6 for pupae and larvae of honey bee, respectively. Nevertheless, insect protein is better in terms of nutritional properties than other sources, since they contain all the essential amino acids (Zielińska, Baraniak, Karaś, Rybczyńska, \& Jakubczyk, 2015). Recent works have exploited the solubility, foamability, gelling ability and emulsifying properties of insect proteins, unrevealing their technological potential (Gould \& Wolf, 2018; Hall, Jones, O'Haire, \& Liceaga, 2017; Mishyna, Martinez, Chen, \& Benjamin, 2019; Mishyna, Martinez, Chen, Davidovich-Pinhas, \& Benjamin, 2019; Zielińska, Karaś, \& Baraniak, 2018). Regarding food applications, insect proteins are being used mainly as dry powder or meals, but more knowledge about technological feasibility and functionality of these proteins are still needed (Lamsal, Wang, Pinsirodom, \& Dossey, 2019; Sosa \& Fogliano, 2017).

\subsection{Microbial protein}

Microbial protein, or "single" cell protein (SCP), is the designation of protein derived from unicellular or even multicellular microorganisms, mainly fungi (yeasts and filamentous fungi), microalgae (cyanobacteria and unicellular eukaryotes) and bacteria. The use of microbial protein for protein supplementation in human diets and animal feeding is not a novel concept, once yeasts have been reported to be employed to supply protein requirements since World War I. However, some drawbacks, such as costs limitation, product quality, protein recovery, high level of nucleic acid and other technical problems, have delayed microbial protein large-scale successful production as we know currently (Goldberg, 1985; Otero, Wagner, Vasallo, \& García, \& Añón, 2000; Reihani \& Khosravi-Darani, 2019).

Microorganism cultivation does not require a large amount of lands as in crops and animal husbandry since microorganisms are usually grown in tanks or reactors, despite the existence of some open ponds systems that are used for microalgae production (Laurens et al., 2017). Another great advantage of microbial protein production is the ecofriendly approach when it is associated with waste treatment. Utilization of agro-industrial by-products, which are low-cost and abundant substrate sources, is a way to produce microbial protein while these wastes are treated by reducing the chemical oxygen demand (Kurcz, Błażejak, Kot, Bzducha-Wróbel, \& Kieliszek, 2018; Reihani \& KhosraviDarani, 2019; Ukaegbu-obi, 2016). A high content of protein (up to 92\%) was reported to photosynthetic bacteria Rhodopseudomonas sp. during biogas slurry treatment under high salinity and high ammonia conditions (A. Yang et al., 2017). Microbial protein may also be a coproduct to be recovered after industrial processes, such spent yeast (Patent No. US 9,963,671 B2, 2018) or algae (Chandra, Iqbal, Vishal, Lee, \& Nagra, 2019; Laurens et al., 2017) from biorefineries and brewery industries (Pietrzak \& Kawa-Rygielska, 2013; Vieira, Cunha, \& Ferreira, 2018). Additionally, molecular biology techniques have been employed to improve or add value to the processes, such as improvement of metabolic routes for the use of agro-industrial wastes in simultaneous production of SCP and lipase by Yarrowia lipolytica (Yan et al., 2018). Although, the use of genetically modified organisms (GMO) lacks public acceptance and stills an issue of discussion (Ritala, Häkkinen, Toivari, \& Wiebe, 2017).

Microbial protein content (Table 1) and quality, in terms of essential amino acids, are variable and depend not only on microorganism species and type of substrate, but also on cell growth stage, nutrient sources and environmental growth conditions (Laurens et al., 2017; Reihani \& Khosravi-Darani, 2019). In general, microbes are considered sources of high-quality protein since they are able to produce essential amino acids in amounts close to $\mathrm{FAO} / \mathrm{WHO}$ reference value of $40 \%$ (FAO/WHO, 2007; Matassa, Boon, Pikaar, \& Verstraete, 2016). Up to $38 \%$ of Chlorella vulgaris protein is composed of essential amino acids, mainly by leucine $(8.2 \%)$ and valine (6.7\%) (Ursu et al., 2014). Similar amounts of essential amino acids were observed in protein from Saccharomyces pastorianus brewery spent yeast (Vieira et al., 2018). Slight lower levels (33\%) of essential amino acids were described for Fusarium venenatum ATCC 20334 which were mainly lysine, valine and phenylalanine (Hosseini \& Khosravi-Darani, 2011).

Protein extracted from microalgae showed emulsifying, foaming and gelling properties (Ba, Ursu, Laroche, \& Djelveh, 2016; Benelhadj, Gharsallaoui, Degraeve, Attia, \& Ghorbel, 2016; Schwenzfeier, Helbig, Wierenga, \& Gruppen, 2013) and may be further explored as a functional agent in foods. In addition to protein content and quality, microbial proteins are sources of nucleic acids, lipids and fats, carbohydrates, vitamins, minerals and, in some cases, pigments (Becker, 2007; Kurcz et al., 2018; Ukaegbu-obi, 2016). Then, microbial protein may be classified as food/feed (regarding nutrition) or additives (as preservatives, colorants, texture modifiers, among others) when aiming at improving or adding functionalities to food/feed preparations (Ritala et al., 2017). In a recent review, Ritala et al. (2017) approached the commercial exploitation of microbial protein and the advances in microbial protein patents for the last two decades. According to these authors, bacteria have been used mainly in animal feed, whereas microalgae and fungi have been used for human consumption as food 
ingredients or supplements, being Arthrospira (Spirulina), Chlorella, Dunaliella, Aphanizomenon, Saccharomyces, Torula, Fusarium and Torulopsis, the main commercially available genera.

\section{Green processing}

Measures to a more efficient and sustainable agri-food industry should not be limited to primary food production and reduced use of products from animal origin, but also be applied to all stages of food supply chain, such as processing set-up, distribution and food by-products management (van der Goot et al., 2016). The disruption of food chain due to spoilage is a key driver for the increase of food waste and an inefficient food distribution, particularly for sub-developed countries, thus contributing to one of the main food paradoxes in the world: obesity versus malnutrition. The development of more efficient and sustainable food processes is then of utmost importance and should guarantee enhanced quality and safety, but also increased energy efficiency, reduced water consumption and mitigation of gas and effluent emissions. Over the last decade, the so-called "green" processing technologies - such as the case of High Hydrostatic Pressure (HHP), Ohmic Heating (OH), Pulsed electric Fields (PEF) - bring new opportunities to re-design food processing, while reducing the environmental footprint and improving nutritional quality of food products without compromising preservation (López-Pedrouso et al., 2019; Pereira \& Vicente, 2010). Fig. 2 shows an example about how OH, PEF and HHP technologies can introduce new variables on food processing (e.g. pressure and electric fields) and contribute to a greener processing by reducing the number of processing operations thus avoiding the excessive use of water, gas emissions and energy. In this section, these technologies will be briefly overviewed, addressing potential contributions and implications on functionality of proteins.

\section{1. $H H P$}

Technologies such as HHP and PEF are in the frontline of nonthermal processing and they have recently been the subject of major interest for the preservation of foods with minimal degradation of its sensorial and nutritional quality. In case of HHP, food materials are subjected to isostatic pressures roughly ranging from 100 to $1000 \mathrm{MPa}$. Application of these high pressures typically can occur at room temperature but can also be combined with adiabatic heating depending on the intended level of microbial inactivation. In accordance with Le Chatelier-Braun principle, the applied pressure level induces molecular counter reactions, despite being irrelevant for small molecules (e.g., vitamins, amino acids and pigmented flavor compounds), that foster non-thermal denaturation of microorganisms and enzymes affecting also the structure and functionality of bio-macromolecules such as proteins (De Maria, Ferrari, \& Maresca, 2016; Pereira \& Vicente, 2010; Rastogi, Raghavarao, Balasubramaniam, Niranjan, \& Knorr, 2007; Shi et al., 2019). Depending on treatment conditions - i.e., pressure, temperature and treatment time - HHP processing can affect from quaternary to secondary structure of proteins, thus influence their unfolding process and protein-protein interactions in a similarly way to that of thermal processing (De Maria et al., 2016). Recent research suggests that HHP can promote conformational changes in globular proteins such as $\beta$-lactoglobulin contributing to its altered allergenicity (Meng, Bai, Gao, Li, \& Chen, 2017).

\section{2. $P E F$}

Regarding PEF, high voltage electrical pulses (usually between $20 \mathrm{kV} / \mathrm{cm}$ and $80 \mathrm{kV} / \mathrm{cm}$ ) are delivered through a food material in microseconds treatment time scale with the objective of inducing electro-permeabilization of biological membranes - a phenomenon known as electroporation (Raso et al., 2016; Rocha et al., 2018). Depending on the electrical protocol applied (number of pulses, pulse

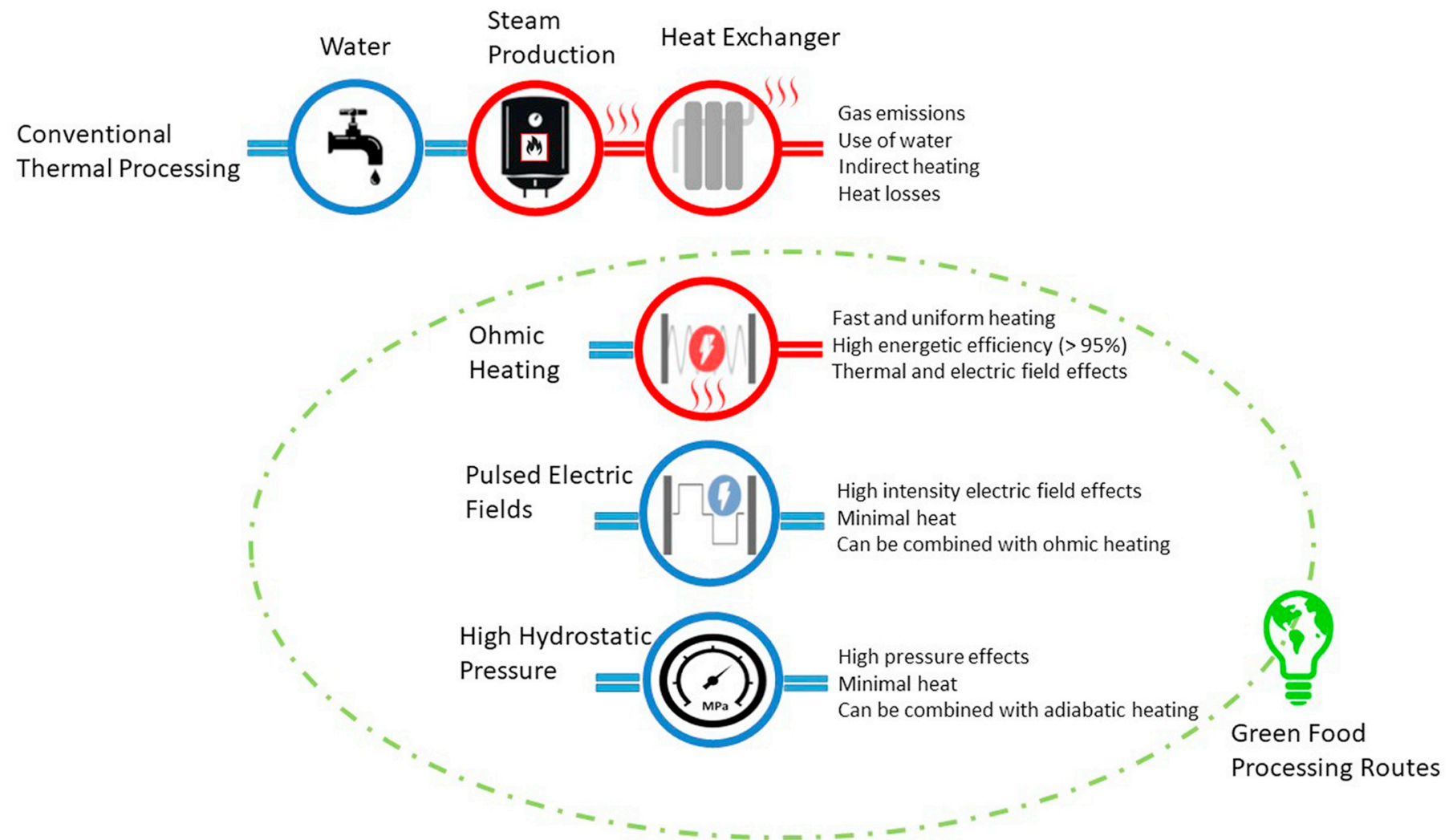

Fig. 2. Reduction of the number of processing operations and environmental footprint through the use of emergent thermal and non-thermal technologies. 
width and intensity, and treatment time) it can be used as an alternative to thermal microbial inactivation of cell suspensions or to permeabilize plant tissues enhancing mass transfer operations (e.g., extraction of biocomponents and nutrients, juice pressing, drying and osmotic dehydration). Combination of PEF treatments with mild heating can be a necessary condition to the inactivation of resistant forms of microorganisms (such as spores and enzymes), but can also be an interesting strategy to increase higher efficiency in the extraction of valuable proteins from vegetables sources (Barba et al., 2015; Puértolas, Luengo, Álvarez, \& Raso, 2012; Timmermans et al., 2019).

\section{3. $\mathrm{OH}$ and moderate electric fields}

$\mathrm{OH}$ is in the origin of electric food processing and supported the appearance of electric field-based technologies such as PEF (Sastry, 2014). Similarly to PEF, its working principle is based on the application of an external electric field through a semi-conductive food material. In the case of $\mathrm{OH}$, the electric fields are of moderate to low intensity $(<1000 \mathrm{~V} / \mathrm{cm})$ with an assigned frequency (i.e. typical from $50 \mathrm{~Hz}$ up to $20 \mathrm{kHz}$ ) (Pataro et al., 2014), being continuously applied in time, allowing internal heat dissipation in a very fast and volumetric way. This technology is bringing a new paradigm to thermal food processing by both reducing excessive thermal load (not dependent on conduction and convection heat transport mechanisms) while benefiting from non-thermal effects of electric fields. Much in part because of these electric effects, another common designation for $\mathrm{OH}$ is moderate electric fields (MEF) processing. Over the last decade it has been highlighted the importance of these MEF on enhancing inactivation of certain type of microorganism and foods enzymes (Cappato et al., 2017; Jaeger et al., 2016; Knirsch, Alves dos Santos, Vicente, \& Penna, 2010; Machado, Pereira, Martins, Teixeira, \& Vicente, 2010). More recently, research studies using $\beta$-lactoglobulin rich fractions as a model system have been pointing out the potential implications that these electrical effects exert on the dynamic behavior and conformational state of protein structure during denaturation and aggregation processes (Pereira et al., 2016; Pereira, Teixeira, \& Vicente, 2011). It was shown that the fast internal heating combined with electrical effects has the ability to reduce size of protein aggregates, as well as to change its morphology and physicochemical aspects during thermal denaturation. These biophysical changes are suggested to be linked with molecular motion imposed by the oscillating electric field particularly when protein structure is more susceptible to thermal structural changes (Rodrigues, Vicente, Petersen, \& Pereira, 2019). These outcomes bring novel perspectives on how $\mathrm{OH}$ can be used to design protein structured systems - such as complexes, emulsions, acidified gels, hydrogels or nanohydrogels - seeking intended functionalities (e.g., development of carrier systems of bioactive compounds, food textural enhancers and improved intestinal absorption). However, because of the effects outlined before, $\mathrm{OH}$ can also change immunoreactivity of produced protein aggregates and the pathways of gastrointestinal digestion which can bring relevant consequence on protein allergenicity (Pereira et al., 2018).

\subsection{Processing and protein functionality}

Overall, the use of the processing technologies aforementioned can enhance preservation, extraction and transformation of important (bio)-macromolecules. Depending on the applied pressure or electric fields intensity, it is possible to induce changes within a given protein structure, thus altering its functional and technological aspects. Novel processing approaches can also be established by a combination of methods such as the case of pulsed ohmic heating (combination of PEF and $\mathrm{OH}$ ), or even fermentation and enzymatic hydrolysis under the influence of MEF. Recently it has been shown that electric fields associated to an electrical frequency and treatment temperature can be used to modulate enzymatic activity of important food enzymes
(Samaranayake \& Sastry, 2016a, 2016b, 2018). These combined approaches may bring synergistic effects and contribute to a larger extent to change biophysical properties of proteins such aggregation, allergenic potential and also digestibility. It is also important to highlight that the effects on protein function of other emergent non-thermal processing methods such as ultrasounds, gamma irradiation, ultraviolet pulsed light and high voltage electrical discharge, as well as thermal ones (such as the case of microwave heating and radiofrequency) are also being discussed but available information on protein function is still limited. The majority of conducted research about the impact of novel food processing have been using preferentially whey and milk proteins (e.g., $\beta$-lactoglobulin and bovine serum albumin) as model systems due to their well-known physicochemical and structural properties. Knowing that these green technologies are increasingly taking a leadership position towards innovation, quality and sustainability in the actual context of food processing, to our understanding is then important to establish more fundamental knowledge about their impact on the safety, quality and functionality aspects of emergent protein sources previously highlighted (Section 2).

\section{Innovative protein systems}

In addition to nutritional factors, several technological-functional properties of proteins in food have been reviewed. Also, the development of protein structures as protective and delivery systems for bioactives have been extensively reported mostly for conventional protein sources. In the past few years, there have been advances in assessing alternative protein sources but there is still much to explore regarding the technological functional properties of emerging proteins. Moreover, with the exception of vegetable proteins, decreasing the working scale to micro and nanosystems using alternative proteins (e.g., insect and microbial protein) still represents a challenge and is a relatively unexplored research field. In this section, the properties of some innovative protein systems in different structure scales are addressed according to the recent findings.

\subsection{Macrosystems and bulky behavior}

During the last decade, many exploratory studies are bringing novel insights about the rheological behavior of these polymers, as well as their behavior in the presence of salts, ions, $\mathrm{pH}$, among others (van Huis, 2013; Yi et al., 2013; Zhao, Vázquez-Gutiérrez, Johansson, Landberg, \& Langton, 2016). Also, solubility/hydrophobicity, thermal behavior, water and oil holding capacity, emulsifying and foamability properties have been characterized for proteins isolated from some vegetables, insects and microbes as shown in Table 2.

The functionalities of vegetable proteins have been explored for longer, thus there are more studies evaluating and comparing their aggregation ability on edible coatings, films and gel formation. Wheat and soybean proteins are probably the most studied vegetable sources. For instance, active films based on glycerol-plasticized wheat gluten protein with thyme essential oil addition were prepared by a thermoplastic process. At the same time, the increase in essential oil content allowed to prepare biodegradable edible films with antioxidant and antimicrobial properties; it also led to more deformable films with lower storage modulus (Ansorena, Zubeldía, \& Marcovich, 2016). In turn, gelling properties of soybean protein from different raw materials (whole and laminate soybean seeds, soy meal obtained of oil extraction residue and dried residue) were recently evaluated (Monteiro \& Lopesda-Silva, 2019). The authors showed that some extent of pre-denaturation decreased the gelation temperature and produced elastic and stiff gels. However, extensive protein denaturation originated water insoluble macro-aggregates that were less available to form a stable three-dimensional network. Due to its known properties and wide applicability in semi-solid foods, gels from soy protein also have been compared to other vegetable proteins. Berghout et al. (2015) showed 
Table 2

Properties and functionalities of emergent proteins reported in literature.

\begin{tabular}{|c|c|c|c|c|c|c|c|c|c|c|c|c|c|}
\hline \multirow[t]{2}{*}{ Group } & \multirow[t]{2}{*}{ Source of protein } & \multicolumn{3}{|c|}{ Behavior } & \multirow[t]{2}{*}{ S/I } & \multicolumn{7}{|c|}{ Functionality studied } & \multirow[t]{2}{*}{ Reference } \\
\hline & & $\mathrm{RB}$ & $\mathrm{MB}$ & TB & & Sol. & WHC & $\mathrm{OHC}$ & Gel. & Film & Emul. & Foam. & \\
\hline \multirow[t]{12}{*}{ Insect } & Alphitobius diaperinus & $\mathrm{X}$ & & & & & & & $\mathrm{X}$ & & & $\mathrm{X}$ & Yi et al., 2013 \\
\hline & Apis mellifera & $\mathrm{X}$ & $\mathrm{X}$ & & $\mathrm{X}$ & & & & $\mathrm{X}$ & & & & $\begin{array}{l}\text { Mishyna, Martinez, Chen, Davidovich-Pinhas, \& } \\
\text { Benjamin, } 2019\end{array}$ \\
\hline & Apis mellifera & & & & $\mathrm{X}$ & $\mathrm{X}$ & & & & $\mathrm{X}$ & $\mathrm{X}$ & $\mathrm{X}$ & Mishyna, Martinez, Chen, \& Benjamin, 2019 \\
\hline & Blaptica dubia & $\mathrm{x}$ & & & & & & & $\mathrm{X}$ & & & $\mathrm{X}$ & Yi et al., 2013 \\
\hline & Grillodes sigillatus & & & & & $\mathrm{X}$ & $\mathrm{X}$ & $\mathrm{X}$ & & & $\mathrm{X}$ & $\mathrm{X}$ & Zielińska et al., 2018 \\
\hline & Grillodes sigillatus & & & & & $\mathrm{X}$ & & & & & $\mathrm{X}$ & $\mathrm{X}$ & Hall et al., 2017 \\
\hline & Schistocerca gregaria & & & & & $\mathrm{X}$ & $\mathrm{X}$ & $\mathrm{X}$ & & & $\mathrm{X}$ & $\mathrm{X}$ & Zielińska et al., 2018 \\
\hline & Schistocerca gregaria & & & & $\mathrm{X}$ & $\mathrm{X}$ & & & & $\mathrm{X}$ & $\mathrm{X}$ & $\mathrm{X}$ & Mishyna, Martinez, Chen, \& Benjamin, 2019 \\
\hline & Teneborio molitor & & & & & $\mathrm{X}$ & $\mathrm{X}$ & $\mathrm{X}$ & & & $\mathrm{X}$ & $\mathrm{X}$ & Zielińska et al., 2018 \\
\hline & Teneborio molitor & $\mathrm{X}$ & & & & & & & $\mathrm{X}$ & & & $\mathrm{X}$ & Yi et al., 2013 \\
\hline & Teneborio molitor & & & & $\mathrm{X}$ & & & & & & $\mathrm{X}$ & & Gould \& Wolf, 2018 \\
\hline & Teneborio molitor & $\mathrm{x}$ & & & & $\mathrm{X}$ & $\mathrm{X}$ & $\mathrm{X}$ & & & & & Zhao et al., 2016 \\
\hline \multirow[t]{7}{*}{ Algae } & Arthrospira platensis & & & $\mathrm{X}$ & $\mathrm{X}$ & $\mathrm{X}$ & $\mathrm{X}$ & $\mathrm{X}$ & $\mathrm{X}$ & $\mathrm{X}$ & $\mathrm{X}$ & $\mathrm{X}$ & Benelhadj et al., 2016 \\
\hline & Arthrospira platensis & & & & $\mathrm{X}$ & $\mathrm{X}$ & & & & & & & Chronakis et al., 2000 \\
\hline & Arthrospira platensis & $\mathrm{x}$ & & $\mathrm{X}$ & & $\mathrm{X}$ & & & $\mathrm{x}$ & & & & Chronakis, 2001 \\
\hline & Chlorella vulgaris & & & & $\mathrm{X}$ & $\mathrm{X}$ & & & & & $\mathrm{X}$ & & Ursu et al., 2014 \\
\hline & Chlorella pyrenoidosa & & & $\mathrm{X}$ & & $\mathrm{X}$ & $\mathrm{X}$ & $\mathrm{X}$ & & & & $\mathrm{X}$ & Waghmare, Salve, LeBlanc, \& Arya, 2016 \\
\hline & Haematococcus pluvialis & & & & $\mathrm{X}$ & $\mathrm{X}$ & & & & & $\mathrm{X}$ & & Ba et al., 2016 \\
\hline & Tetraselmis sp. & & & & $\mathrm{X}$ & $\mathrm{X}$ & & & & & $\mathrm{X}$ & & Schwenzfeier et al., 2013, 2011 \\
\hline \multirow[t]{6}{*}{ Fungi } & Kluyveromyces fragilis & & & $\mathrm{X}$ & & $\mathrm{X}$ & $\mathrm{X}$ & & & & & & Otero et al., 2000 \\
\hline & Kluyveromyces fragilis (CWP) & $\mathrm{X}$ & & & $\mathrm{X}$ & & & & & & $\mathrm{X}$ & $\mathrm{X}$ & del Carmen Vasallo et al., 2006 \\
\hline & Saccharomyces cerevisiae (WC) & & & & & & $\mathrm{X}$ & $\mathrm{X}$ & $\mathrm{X}$ & & & $\mathrm{X}$ & Bacha et al., 2011 \\
\hline & Saccharomyces cerevisiae & & & $\mathrm{X}$ & $\mathrm{X}$ & $\mathrm{X}$ & & & & & & & Sceni et al., 2009 \\
\hline & Saccharomyces cerevisiae & & & $\mathrm{X}$ & & $\mathrm{X}$ & $\mathrm{X}$ & & & & & & Otero et al., 2000 \\
\hline & Saccharomyces cerevisiae (CWP) & $\mathrm{x}$ & & & & $\mathrm{X}$ & & & & & $\mathrm{X}$ & & Li \& Karboune, 2019 \\
\hline \multirow[t]{11}{*}{ Vegetable } & $\begin{array}{l}\text { Beans (common, speckled sugar bean and } \\
\text { Great northern) }\end{array}$ & & & & $\mathrm{X}$ & $\mathrm{X}$ & & & & & $\mathrm{X}$ & & Rahmati, Koocheki, Varidi, \& Kadkhodaee, 2018 \\
\hline & Bitter vetch & & $\mathrm{X}$ & & & $\mathrm{X}$ & & & & $\mathrm{X}$ & & & Arabestani, Kadivar, Shahedi, Goli, \& Porta, 2016 \\
\hline & Chia & $\mathrm{x}$ & & & $\mathrm{X}$ & & $\mathrm{X}$ & & $\mathrm{X}$ & & $\mathrm{X}$ & & López et al., 2018 \\
\hline & Chickpea & & & $\mathrm{X}$ & & $\mathrm{X}$ & & & & & $\mathrm{X}$ & & Mokni Ghribi et al., 2015 \\
\hline & Lupin & $\mathrm{X}$ & & $\mathrm{X}$ & & & & & $\mathrm{X}$ & & & & Berghout et al., 2015 \\
\hline & Lupin & & & & & $\mathrm{X}$ & & & & & $\mathrm{X}$ & $\mathrm{X}$ & Burgos-Díaz et al., 2016 \\
\hline & Oat & & $\mathrm{X}$ & $\mathrm{X}$ & & & $\mathrm{X}$ & & $\mathrm{X}$ & & & & Nieto-Nieto, Wang, Ozimek, \& Chen, 2014 \\
\hline & Pea & & & & $\mathrm{X}$ & $\mathrm{X}$ & $\mathrm{X}$ & & & & $\mathrm{X}$ & $\mathrm{X}$ & $\begin{array}{l}\text { Stone, Karalash, Tyler, Warkentin, \& Nickerson, } \\
2015\end{array}$ \\
\hline & Soy & & $\mathrm{X}$ & $\mathrm{X}$ & & & & & $\mathrm{X}$ & & & & Berghout et al., 2015 \\
\hline & Soy & & $\mathrm{X}$ & $\mathrm{X}$ & & $\mathrm{X}$ & & & & $\mathrm{X}$ & & & Denavi et al., 2009 \\
\hline & Wheat gluten & & $\mathrm{X}$ & $\mathrm{X}$ & & & & & & $\mathrm{X}$ & & & Ansorena et al., 2016 \\
\hline
\end{tabular}

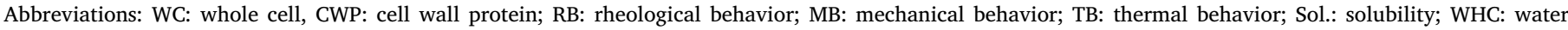
holding capacity; OHC: oil holding capacity; Gel.: Gelling ability; Emul.: Emulsifying; Foam.: Foamability; S/I: Surface/ interfacial properties.

that lupin protein isolate behaved differently from soy protein isolate, being unable to form gels with similar consistency and deformability, which has been attributed to the different concentration of free sulfhydryl groups. Lam, Can Karaca, Tyler, and Nickerson (2018) published a review about pea protein isolates, where they included results about cold-set gelation and effect of $\mathrm{pH}$, salts, structural changes on its heating-set gelling behavior. On the other hand, López et al. (2018) evaluated the effects of extraction $\mathrm{pH}$ on the functional properties of chia protein isolates. They showed that the heat-induced gelation of proteins extracted at $\mathrm{pH} 10$ and 12 resulted in weak gels. Besides wheat and soybean proteins, lupin, chickpea, zein, moringa, amaranth, quinoa and rapeseed are examples of the numerous vegetables that had their technological-functional properties unraveled recently. There are interesting recent works and reviews about these proteins, addressing their functionality besides their structure and extraction procedures. Jones (2016) published recent advances about the functional properties of some oilseed and pulse proteins and prolamins. The author concluded that soybean, rapeseed, pea and chickpea proteins have best functional properties.

Insect proteins as gelling agents are still poorly investigated, while to the best of our knowledge there are no works using these proteins to produce edible films and coatings. For this reason, the aggregation and gelation mechanisms of proteins from insects are still not well understood. For example, yellow mealworm (Tenebrio molitor), lesser mealworm (Alphitobius diaperinus), house cricket (Acheta domesticus), superworm (Zophobas morio), and Dubia cockroach (Blaptica dubia) proteins gelled only at neutral and alkaline $\mathrm{pH}$ at a concentration of $30 \%(w / v)$ (Yi et al., 2013). They evaluated the gelling behavior at $\mathrm{pH} 7$ through changes in rheology and found that gelation occurred from about $51{ }^{\circ} \mathrm{C}$ to $63^{\circ} \mathrm{C}$ for all these species. On the other hand, Mishyna, Martinez, Chen, and Benjamin (2019) evaluated the heat-induced aggregation of proteins from honey bee brood (Apis mellifera) and grasshopper (Schistocerca gregaria). Honey bee brood showed significantly higher coagulation than grasshopper (Mishyna, Martinez, Chen, Davidovich-Pinhas, \& Benjamin, 2019). Moreover, proteins from honey bee brood showed maximum aggregation at $85^{\circ} \mathrm{C}$ (for $\mathrm{pH} 5$ and 7). The authors attributed the mechanism of aggregates formation to covalent and non-covalent intermolecular interaction. Moreover, hydrophobic domains were more exposed under heating at $\mathrm{pH} 5$ and 7, contributing to higher protein aggregation (Mishyna, Martinez, Chen, DavidovichPinhas, \& Benjamin, 2019).

Most studies regarding microbial protein have focused on characterization of protein extracts according to nutritional quality in terms of essential amino acids composition (Gerde et al., 2013; Vieira, da Silva, Carmo, \& Ferreira, 2017), while protein functionalities were investigated in a lower extent (Table 2). Minimum critical gelling concentration for protein isolate from Arthrospira platensis (Spirulina platensis) was $12 \%(w / \mathrm{w})$ after boiling and cooling (Benelhadj et al., 
2016). Lower values for other strains of the same species were reported by Chronakis (2001). In this case, the protein isolate was described as a protein-pigment complex and its least gelling concentration was $1.5 \%$ $(\mathrm{w} / \mathrm{w})$ in $\mathrm{pH} 7$ buffer solution, or $2.5 \%(\mathrm{w} / \mathrm{w})$ with salt addition $(0.02 \mathrm{M}$ $\mathrm{CaCl}_{2}$ ). Authors suggested that hydrophobic interactions showed a significant role in protein gelation, contributing to molecular association, initial aggregation, and stability of the gels (Chronakis, 2001). The yeast Saccharomyces cerevisiae also showed complete gelation at low concentration (3.5\% w/v) (Bacha, Nasir, Khalique, Anjum, \& Jabbar, 2011). However, in this case, proteins were not previously extracted, and gelation properties may be substantially enhanced by interaction with other cellular components. Indeed, it is shown that proteins properties and functionalities are dependent on extraction conditions (Ursu et al., 2014), purity degree of extracts and microbial source (Otero et al., 2000). Moreover, according to (Otero et al., 2011; Sceni et al., 2009), membrane and cell wall lipoproteins and mannoproteins show best surface properties while hydration and gelling properties are driven mainly by cytoplasm and nuclear proteins. These properties may be correlated to the lower water solubility of yeast cell wall films when compared to other biopolymer films (Peltzer, Salvay, Delgado, de la Osa, \& Wagner, 2018). Or with the emulsifying properties of mannoproteins isolated from Saccharomyces cerevisiae cell wall that were close to commercial lecithin (Li \& Karboune, 2019).

\subsection{Microsystems}

Proteins obtained from vegetable sources can be designed as effective wall materials for microencapsulation of different bioactive compounds. Pea protein has been successfully used to microencapsulate conjugated linoleic acid (Costa et al., 2015), $\alpha$-tocopherol (Pierucci, Andrade, Farina, Pedrosa, \& Rocha-Leão, 2007), ascorbic acid (Pierucci, Andrade, Baptista, Volpato, \& Rocha-Leão, 2006) and Propolis extract (Jansen-Alves et al., 2019). Also, chick pea protein has been used to encapsulate folate, conferring greater stability to folate relative to unencapsulated folate (Ariyarathna \& Nedra Karunaratne, 2015). In this case, values of $62.19 \pm 2.05 \%$ and $10.18 \pm 0.89 \%$ have been obtained for encapsulation efficiency and loading capacity, respectively and a gradual release of folate was observed in the $\mathrm{pH}$ range of 2-8.

Vegetable proteins such as lentil (Can Karaca, Nickerson, \& Low, 2011; Wang, Ghosh, \& Nickerson, 2019), chickpea (Can Karaca et al., 2011; Felix, Cermeño, Romero, \& FitzGerald, 2019), lupin (Burgos-Díaz et al., 2018) and soy (Zang et al., 2019) have been also used as emulsifiers to facilitate the formation, improve the stability and provide specific physicochemical properties to emulsions (Burgos-Díaz, Wandersleben, Marqués, \& Rubilar, 2016). However, the pH sensitivity of vegetable-based proteins could not be neglected, being frequently necessary to find strategies to further increase emulsions' stability. Combination of vegetable proteins with polysaccharides may improve their emulsifying properties and stability against extreme conditions. In fact, it has been shown that multilayer emulsions (with droplet diameter $<80 \mu \mathrm{m}$ ) can be prepared by the layer-by-layer technique using a protein isolate from the novel high yielding protein lupin crop (AluProt-CGNA) combined with chitosan and xanthan gum (Burgos-Díaz et al., 2016). Although, lupin protein-stabilized emulsions showed to be highly unstable to aggregation at $\mathrm{pH}$ values around their isoelectric point $(\mathrm{pH} \sim 4.6)$ and temperatures of $30-90^{\circ} \mathrm{C}$, their stability to aggregation over a wide range of $\mathrm{pH}$ values, temperature, and salt concentrations have been improved by the addition of chitosan and xanthan gum layers. In the same way, other authors used unmodified protein isolates from lupin, pea and broad beans as emulsifiers and showed that all emulsions precipitated at their isoelectric point, whereas emulsion stability increased by the presence of a polysaccharide (Makri, Papalamprou, \& Doxastakis, 2005). Also, it has been shown that structural changes in pea proteins, as a result of alkaline $\mathrm{pH}$ treatment, improved the physical and oxidative stability of emulsions (Jiang, Zhu, Liu, \& Xiong, 2014).
Although much less explored, proteins extracted from insects and microalgae can be used as emulsifiers in oil-in-water emulsions. For example, protein extracted from mealworm (Tenebrio molitor) have shown interfacial activity and fast adsorption kinetics at the oil/water interface. Also, the mealworm protein stabilized oil-in-water emulsions showed to be stable to changes in $\mathrm{pH}$, salt and temperature, except for flocculation after heating at $90{ }^{\circ} \mathrm{C}$ and $\mathrm{pH}$ close to proteins' isoelectric point (Gould \& Wolf, 2018). Similarly, a soluble protein fraction isolated from the green microalgae Tetraselmis sp. allowed the formation of stable emulsions in the $\mathrm{pH}$ range of 5-7 at low protein concentrations (Schwenzfeier et al., 2013).

\subsection{Nanosystems}

Nanotechnology is an emerging field in the food industry due to its great potential to improve food productivity by enhancing food processing conditions, as well as to allow obtaining high quality, safer and healthier food products (Cerqueira et al., 2017; de Souza Simões et al., 2017). Hence, the use of materials at nano scale $\left(10^{-9} \mathrm{~m}\right)$ may display distinct physical-chemical and biological properties that can lead to novel material functionalities, in comparison to those in the bulk form, due to the higher surface area-volume ratio obtained at this scale (Madalena, Pereira, Vicente, \& Ramos, 2019). In food industry, the use of nanomaterials can be particularly useful for the encapsulation and delivery of bioactive compounds (e.g., vitamins, nutrients, minerals, antioxidants, antimicrobials, prebiotics and probiotics) intended for the development of novel and more efficient functional food products. Due to the reduced size of nanosystems, they can enhance the solubility and sensorial features (e.g., mask unpleasant flavors), preserve the activity, prevent oxidative reactions, or even improve the bioaccessibility and bioavailability of bioactive compounds (Durán \& Marcato, 2013; Pisoschi et al., 2018; Rehman et al., 2019; R. Yang et al., 2018).

The development of functional foods enriched with nanosystems has been an emerging focus of food industry as a novel approach either to 1) fight the rising world malnutrition, particularly relevant in underdeveloped countries; 2) address the micronutrient deficiency that frequently result in severe health-related problem in developing countries due to modern eating habits and inadequate diets; or 3 ) face the growing consumer demands for healthy foods with additional properties (e.g., antioxidant, anti-cancer and anti-inflammatory) in addition to their nutritional value (Bao et al., 2019; da Silva Santos, Badan Ribeiro, \& Andrade Santana, 2019; Guiné, Ramalhosa, \& Paula Valente, 2016; Kasaai, 2018; Ramos et al., 2017)

However, the successful use of nanosystems in food applications dependents on the full replacement of non-food-grade materials by food-grade and generally recognized as safe (GRAS) alternatives (Cerqueira et al., 2014; Ramos et al., 2019), and on the consumers' acceptance of nanotechnology-based products (Cerqueira et al., 2017). For food industry applications, nanosystems can be produced from a wide range of food-grade materials such as proteins, polysaccharides and lipids, or their combination, to form complex delivery systems (e.g. capsules, hydrogels and emulsions) (Cerqueira et al., 2014; de Souza Simões et al., 2017; Madalena et al., 2019; Ramos et al., 2019). Among the distinct food-grade materials, protein-based nanosystems have particular interest because they are biodegradable, metabolizable, easily manipulated and functionalized (e.g. surface alteration and/or modification) for covalent binding with bioactive compounds (Madalena et al., 2016; Monteiro et al., 2016; Ramos et al., 2017; Tarhini et al., 2017).

Vegetable proteins such as zein and gliadin are GRAS materials that have shown a great potential to be used in the design of nano delivery systems. These proteins may not need the use of chemical agents or physical treatment for the development of nanosystems due to their high hydrophobicity. Moreover, they are less expensive than animal proteins and also have important functional groups able to adsorb or to covalently bind agents capable of altering the targeting properties of 
nanoparticles. Motivated by this, Li et al. (2019) developed nanoparticles from zein as base material and soybean as stabilizer for quercetin encapsulation. These systems exhibited a particle size of ca. $200 \mathrm{~nm}$ and encapsulation efficiency of $82.5 \%$, showing to be relatively stable at high ionic strength and temperature (Li et al., 2019). Patel, Hu, Tiwari, and Velikov (2010) synthesized polymeric colloidal nanoparticles from zein for curcumin encapsulation. These nanoparticles displayed particle sizes between 100 and $150 \mathrm{~nm}$, and curcumin loading and encapsulation efficiency from 1.6 to $4.1 \%$ and 71.1 to $86.8 \%$, respectively, and exhibited a good colloidal stability at an extensive range of physiologically relevant $\mathrm{pH}(1.2,4.5,6.7$ and 7.4) and in simulated gastrointestinal conditions (Patel et al., 2010). Wu, Luo, and Wang (2012) designed nano delivery systems from zein using the liquid-liquid dispersion method for encapsulation of thymol and carvacrol essential oils to improve their solubility without affecting their intrinsic antimicrobial and antioxidant properties. These nanosystems showing particle sizes below $320 \mathrm{~nm}$ and an encapsulation efficiency higher than $50 \%$ for both essential oils, were able to improve the solubility of thymol and carvacrol up to 14-fold without hindering their ability to scavenge free radicals or to control Escherichia coli growth, for example (Wu et al., 2012).

$\mathrm{Hu}$ and McClements (2015) developed promising nano-delivery systems from zein (as core matrix) and alginate (as shell) exhibiting a high stability (at $\mathrm{pH}$ ranging from 3 to 8 and at ambient and refrigeration temperatures) for encapsulation and controlled release of bioactive molecules. In another work, Wu, Kong, Zhang, Hua, and Chen (2018) produced nanoparticle with wheat gliadin proteins (as base material) and gum arabic (as stabilizing agent), exhibiting good stability (at pH comprised from 4.0 to 7.0 and at $80^{\circ} \mathrm{C}$ ), which are important properties for successful delivering bioactive compounds. Wang et al. (2015) developed innovative nanofibrous membranes from poly (vinyl alcohol) and wheat gluten as base matrix that showed improved release rates of nisin, and thus better antimicrobial activity against Staphylococcus aureus. These are very promising characteristics that can be highly explored in drug delivery, wound dressing and active food packaging. In another study, Verdugo, Lim, and Rubilar (2014) used protein concentrate from microalgae Botryococcus braunii residual biomass as base material to develop nano and microfibers by electrospinning. The work presented by these authors revealed a great potential of these fibers for many end-use applications, including in the food and biomedical industries.

The use of nanosystems for food applications, although promising and prepared from renewable and sustainable sources (mainly from vegetable proteins), may present risks for human health that should not be overlooked. Therefore, potential risks should be clearly identified regarding the unknown effects of such nanosystems in the human body and within the ecosystem (Cerqueira et al., 2014; de Souza Simões et al., 2017).

\section{Health considerations}

When introducing proteins from novel sources into the human diet, it is essential to take in consideration their behavior and bioavailability throughout the gastrointestinal tract and also assess their possible cytotoxic effects or other negative impacts on human health (e.g. allergic reactions).

\subsection{Digestibility}

Protein or protein fractions, able to resist human digestion and to be directly absorbed by the intestinal epithelium, have the potential to affect consumers' health by either exerting positive (e.g., nutraceutical) or negative (e.g., antinutritional and allergenic) effects (Ribeiro et al., 2017). In fact, stability to gastrointestinal digestion is one of the major characteristics shared by allergenic proteins (Astwood, Leach, \& Fuchs, 1996) being, therefore, in vitro digestion experiments (i.e., testing proteins for their resistance to gastric fluids) frequently used to assess the allergenic potential of novel food proteins. The digestion susceptibility of lupin seed globulins has been evaluated and it was shown that globulins are completely hydrolyzed by pepsin, pepsin followed pancreatin or chymotrypsin, whereas, pancreatin and trypsin did not hydrolyze all globulins. The protein fraction resistant to the action of these enzymes was $\gamma$-conglutin, which retained its antigenic properties after digestion. Its insensitivity to hydrolysis by pancreatin and trypsin was attributed to the formation of complexes with the flavonoids released from other protein connections during digestion, as well as to the low number of cleavage sites for trypsin (Czubiński, Siger, \& LampartSzczapa, 2016). Other authors identified and characterized chickpea seed proteins as being able to resist to in vitro simulated human digestion. It was found that the majority of these proteins were members of the $7 \mathrm{~S}$ vicilin and $11 \mathrm{~S}$ legumin seed storage protein classes, which are reported to exhibit bioactive functions (Ribeiro et al., 2017). However, the results of proteins' digestibility should be analyzed with care once, contrary to what would be expected, it was found that some potent allergens are not stable in gastric fluids, being rapidly digested $(\mathrm{Fu}$, Abbott, \& Hatzos, 2002). This indicates that using digestion stability as criteria provides important, but not sufficient, information to predict the allergenic potential of proteins (Untersmayr \& Jensen-Jarolim, 2008).

It is known that proteins' digestion kinetics may be influenced by different factors including processing conditions, $\mathrm{pH}$ during processing and interactions with other components present in the food matrix. Recently, the influence of $\mathrm{pH}$ and processing conditions on the digestibility of pea protein isolate have been investigated (Laguna, Picouet, Guàrdia, Renard, \& Sarkar, 2017). These authors found that HHP processing enhanced the degree and rate of proteolysis, which can be attributed to globular pea protein subunits unfolding. Also, the initial $\mathrm{pH}$ showed a strong effect on extent and degree of digestibility, being pea protein at pH 6.2 more digestible owing to their higher solubility at this $\mathrm{pH}$. Other authors showed the influence of different processing treatments and the use of enzymes (isolated or in combination) on lentil protein digestion (Aryee \& Boye, 2016). It was evidenced that mild processing methods (e.g., pre-hydrolysis using enzymes) could be used to render peptide bonds more accessible to digestive proteases.

Protein quality and postprandial protein gain are not only influenced by the amino acid content but also by the bioavailability of the protein, which in part depends on their digestibility. Different species of edible insects have been analyzed in terms of their protein digestibility (Ramos-Elorduy et al., 1997) and values from $76 \%$ to $96 \%$ have been obtained, which are comparable to the ones found for egg proteins (95\%) or beef (98\%) and higher than the ones found for many vegetable proteins (Kouřimská \& Adámková, 2016). Also, digestibility of globulin proteins isolated from fava bean and lupin (using a rat small intestine) has been demonstrated to be well over 90\% (Rubio, Grant, Caballé, Martinez-Aragón, \& Pusztai, 1994). In turn, protein from microalgae appear to have similar digestibility to that of seaweed, with Scenedesmus obliquus, Spirulina sp. and Chlorella sp. having digestibility coefficient values of $88.0 \%, 83.9 \%$ and $89.0 \%$, respectively (Becker, 2007). However, there is a major obstacle for microalgae utilization as protein source that is the presence of a cellulosic cell wall, representing about $10 \%$ of their dry weight, which is not digested by humans. Therefore, in order to make microalgae protein accessible for digestive enzymes, effective processing treatments are typically necessary to disrupt the cell wall.

The effect of microbial protein produced by Corynebacterium ammoniagenes on ileal amino acid digestibility in pigs has been also evaluated and compared with soybean proteins (Wang, Kim, Kim, \& Kim, 2013). A lower digestibility of microbial protein by pigs has been observed, which has been attributed to its higher non-protein nitrogen content (e.g., nucleotide) as compared with soybean.

Also, it is important to mention that the resistance of specific protein domains to digestion is not the only condition for exerting an 
immunological response. Protein allergenicity during/after gastrointestinal digestion could increase due to the creation of neopitopes resulting from native state protein digestion, or due to the increase in epitope concentration and their affinity to immune system cells (e.g., B cells) (Groell, Jordan, \& Borchard, 2018). Moreover, digestion induced conformational changes (e.g. unfolding or aggregation) of the linear (sequential) or conformational (discontinuous) epitopes which could influence the allergenicity (Matsuo, Yokooji, \& Taogoshi, 2015; Picariello et al., 2010; Kitty Verhoeckx et al., 2019). For instance, Ara h 1 (a major peanut allergen) can form a stable trimer complex that offer protection from protease digestion and denaturation, which could allow Ara $h 1$ (with intact IgE-binding epitopes) to pass through the small intestine, leading to allergenicity (Sen et al., 2002).

\subsection{Cytotoxicity}

Many novel proteins and peptides present a great prospective as functional food ingredients or supplements, but not only their resistance to human digestion but also their quality and availability must be evaluated. Complementary safety information may be mandatory to investigate whether proteins or peptides from different sources such as seaweed, microalgae and insects, could be considered safe for consumption (Loveday, 2019; van der Spiegel, Noordam, \& van der FelsKlerx, 2013).

Proteins and peptides toxicity take a central part in the regulation of body functions. Protein chemical or non-chemical modifications could result in nutritional value changes, possible toxic peptides or amino acid derivatives formation, and contamination by toxic chemicals harmful for health (Hurley et al., 2016; Zimmermann et al., 2018). Analyses intending to establish the proteins' cytotoxicity properties have to consider a range of factors (e.g., proteins' effect on the gastrointestinal tract and susceptibility to digestion - see section 5.1). Therefore, the application of in vitro assays as screening tools can assist in estimating the potential proteins toxicity prior to their test in animal models and clinical studies. The cytotoxic effects of proteins usually are evaluated using in vitro assays such as 3-(4,5 dimethylthiazol-2-yl)- 2,5diphenyltetrazolium bromide (MTT) test based on mitochondrial dehydrogenase activity detection in living cells and lactate dehydrogenase (LDH) released from dead cells (Hurley et al., 2016). Additionally, necrosis, apoptosis and/or cell cycle disturbances activities are assessed in many research works with the purpose to clarify about cell death mechanism stimulated by protein or peptides (Chalamaiah, Yu, \& Wu, 2018). Recently, it has been shown that protein derived from the fungus Cordyceps militaris increased cell cytotoxicity (measured using MTT and LDH assays) in murine primary cell line possibly through mitochondrion-dependent apoptosis (Bai \& Sheu, 2018). Zimmermann et al. (2018) evaluated the cell viability by LDH release, MTT conversion and barrier integrity of human intestinal epithelial cell monolayers (Caco-2 and T84 IEC) exposed to hazardous (e.g., wheat germ agglutinin) and non-hazardous (e.g., bovine serum albumin (BSA)) proteins for $24 \mathrm{~h}$, $48 \mathrm{~h}$ and $72 \mathrm{~h}$. The authors demonstrated that non-hazardous proteins did not have influence on Caco-2 and T84 IEC cells after $24 \mathrm{~h}$ of exposure. On the other hand, barrier integrity or cell viability decreased after exposure to hazardous proteins for $24 \mathrm{~h}$, being this result more evident after $48 \mathrm{~h}$ and $72 \mathrm{~h}$ for both intestinal epithelial cells. Also, the safety of insect-derived protein hydrolysates has been evaluated using in vitro cytotoxicity assays. Zielińska et al. (2015) studied the cytotoxicity effect of raw, cooked and baked protein hydrolysates from Tenebrio molitor, Schistocerca gregaria and Gryllodes sigillatus to human skin fibroblasts CRL-2522. Authors indicated that hydrolysates from $T$. molitor and G. sigillatus had no cytotoxic effects (before and after heat treatment). On the other hand, S. gregaria hydrolysate (particularly, raw samples) showed cytotoxic effects (up to $40 \%$ cell death) towards fibroblast CRL-2522.

Moreover, cytotoxicity studies have provided evidence that proteins derived from non-animal and animal sources could exhibit anticancer and antioxidant activities (Beltrán-Barrientos et al., 2017; Premkumar \& Vasudevan, 2018). For example, Rayaprolu et al. (2017) characterized protein hydrolysate fractions from a high oleic acid soybean. The factions obtained (10-50 $\mathrm{kDa}$ fraction peptides) were tested on blood (CCRF-CEM), colon (Caco-2 and HCT-116), and liver (HepG-2) cancer cell lines for their inhibitory effects on cancer cell proliferation. Peptides were found to exhibit anti-proliferation activity on the three types of cancer cells. In another study, Chalamaiah, Hemalatha et al. (2015) assessed the anticancer properties of protein hydrolysates derived from rohu (Labeo rohita) roes (eggs) by enzymatic hydrolysis (using pepsin or trypsin) against human colon cancer cell line (Caco-2). The results showed that pepsin protein hydrolysate exhibited $65 \%$ antiproliferative activity on Caco-2 cells. Furthermore, antioxidant activity and cytotoxicity properties of peptides derived from microalgae Navicula incerta (by enzymatic hydrolysis) in HepG2/CYP2E1 cells have been studied (Kang, Qian, Ryu, Kim, \& Kim, 2012). Results showed that $N$. incerta peptides attenuated the ethanol-induced cytotoxicity of HepG2 cells. Other study showed that Chlorella pyrenoidosa-derived peptide provides protective effects against UVC-induced cytotoxicity in human skin fibroblasts (Shih \& Cherng, 2012). Lastly, the capacity of germinated soybean peptides to affect the viability of three human colon cancer cell lines (Caco-2, HT-29, and HCT-116) was evaluated (González-Montoya, Hernández-Ledesma, Silván, Mora-Escobedo, \& Martínez-Villaluenga, 2018). Peptides fractions $<5,5-10$, and $>10 \mathrm{kDa}$ caused cytotoxicity to Caco-2, HT-29, HCT-116 cells. The authors suggested that the antiproliferative effect of germinated soybean peptides in human colon cell lines may be due to induction of apoptosis.

Also, experimental animal models for human risk assessment were used to determine protein cytotoxicity. For instance, Canistro et al. (2017) studied rapeseed and sunflower protein hydrolysates toxicity and metabolic effects in a murine animal model. This study showed no toxicity effect of the protein hydrolysates diet on mice, since no changes were detected on growth, organ weight, blood biochemical and food intake parameters.

\subsection{Allergenicity}

Food allergies are growing considerably among the world population, particularly in infants. Very severe allergic reactions against ingested foods, mainly to dairy proteins, lead to anaphylaxis. Food allergic reactions are described as adverse reactions to health (from local and transient effects to systemic anaphylaxis) that induce specific immune response in susceptible subjects following dietary exposure to relevant allergens in food (Verhoeckx et al., 2015). In a broad sense, allergic food reactions can include immunoglobulins (IgE) and non-IgEmediated primary immunological sensitivities, non-immunological food intolerances, and secondary sensitivities (Taylor \& Hefle, 2001). The main form of immune-mediated allergic reactions to foods is linked to IgE formation against food allergens (Type I reactions). Some frequent food inducers of IgE-associated allergy are egg, milk, fish, wheat, nuts, vegetables and fruits (Valenta, Hochwallner, Linhart, \& Pahr, 2015). Normally, an allergic reaction occurs when IgE antibodies are produced and bind to the ingested proteins. Consequently, IgE is bound to the surface of effectors' cells (basophils or mast cells), leading them to release mediators such as histamine, leukotrienes and cytokines, resulting in allergic response directly at the sites of allergen contact (e.g., mouth and intestine) or in other organs, when allergens are able to pass through the mucosa barrier into the blood circulation (Valenta et al., 2015).

Peptides derived from diverse sources (e.g., milk, egg, soybean, fish and nuts) have been shown to strongly influence the immune system. Vegetable proteins have attracted significant interest compared to animal proteins, due to their potential non-allergenicity. Thus, in addition to cytotoxicity, the incidence of allergic reactions following novel protein consumption (e.g., from insect origin) has been assessed (Parenti, Santoro, Del Rio, \& Franceschi, 2019). The majority of studies 
explored the proteins' immunomodulatory properties and their influence on inflammatory cytokine production, antibodies production, and lymphocyte activity and proliferation (Parenti et al., 2019). One study reported that oral administration of carp egg protein hydrolysates (CEPHs) (pepsin hydrolyzed) to female BALB/c mice significantly enhanced humoral immune response because immunoglobulin A (IgA) antibody production increase in serum. Moreover, the splenic natural killer (NK) cells cytotoxicity increased in the gut, which indicates a host capacity improvement to fight against tumor cells and virus-infected cells (Chalamaiah, Jyothirmayi et al., 2015).

In this framework, many technological novel and emergent food process applications (e.g., OH, PEF, HHP and enzymatic treatment) could contribute to avoid or limit proteins' allergenicity, at least for some classes of allergic groups, by changing the allergen appearance or cleaving the allergenic protein epitopes. Some reviews (Chizoba Ekezie, Cheng, \& Sun, 2018; Rahaman, Vasiljevic, \& Ramchandran, 2016; Verhoeckx et al., 2015) have gathered information about the potential effect of food processing technologies on the reduction of various proteins' allergenicity. For instance, ovalbumin (one of the most important sensitizing ingredients in allergens of egg albumin) was submitted to a pre-heating treatment integrated with glycation, and allergenicity was estimated by indirect competitive ELISA. The results showed that allergenicity decreased because IgG/IgE-binding capability of ovalbumin was dramatically reduced due to $\operatorname{IgG}$ and $\operatorname{IgE}$ epitopes cover and ovalbumin structural changes (Liao et al., 2018). It should be also highlighted that protein allergenicity could increase, as well the formation of neoallergenic species, due to food processing. For example, allergenicity of soy protein isolate (SPI) treated by enzymatic hydrolysis with alcalase, trypsin, chymotrypsin, bromelain, or papain was evaluated by in vitro IgE binding. Results showed that SPI enzymatic hydrolysis did not reduce the allergenicity, and chymotrypsin or bromelain hydrolysis could increase SPI allergenicity (Panda, Tetteh, Pramod, \& Goodman, 2015). Moreover, research works showed that non-thermal treatments, like ultrasonication, microwave and HHP could possibly change food allergenicity (Pojić, Mišan, \& Tiwari, 2018). For example, SPI allergenicity for infant formulae decreased $24.7 \%$ due to a microwave treatment that changed proteins' secondary structure (Li, Zhu, Zhou, Peng, \& Guo, 2016). The same authors also decreased SPI allergenicity by $18.9 \%, 29.8 \%$ and $46.6 \%$ using high-intensity ultrasound, high-pressure homogenization and HHP, respectively (Li et al., 2016). In another study, Li, Zhu, Zhou, and Peng (2012) demonstrated the reduction of SPI allergenicity (48.6\%) as compared to non-treated SPI due to HHP at $300 \mathrm{MPa}$ for $15 \mathrm{~min}$.

Another way to reduce the potential protein allergenicity is to use capsules (e.g., nanocapsules) as protein carriers to avoid the activation of immune cells through antibodies identification (Pohlit et al., 2015). Gamazo, Gastaminza, Ferrer, Sanz, and Irache3, J. M. (2014) reviewed the use of nanoparticles as delivery systems to carry protein allergens.

Furthermore, a complete allergenicity risk assessment is needed (according to the European Food Safety Authority (EFSA) legislation) to approve novel protein sources as potential food ingredients taking into consideration various aspects such as route (e.g., oral) and dose of protein exposure, protein properties (e.g., physicochemical properties) and how protein is perceived by each person's immune system (Parenti et al., 2019). Different strategies can be used to assess allergenicity risks (Crevel et al., 2014; Fernandez, Mills, Koning, \& Moreno, 2019). One of these strategies is a "weight-of-evidence approach" used for food derived from genetically modified plants (Verhoeckx, Broekman, Knulst, \& Houben, 2016). The allergenicity risk assessment conclusion is the probability of a protein being an allergen. This strategy focuses on cross-reactivity; however, the novel (or modified) proteins can also cause a risk of de novo sensitization, which could lead to novel food allergies (Pali-Schöll et al., 2019). Some relevant methods for protein allergenic risk assessment were described by other authors (Mazzucchelli et al., 2018). The assessment of protein transport across the intestinal barrier, as well as its implication on epithelial permeability are important factors in allergenicity risk assessment
(Reitsma, Westerhout, Wichers, Wortelboer, \& Verhoeckx, 2014). The application of diverse epithelial cell models to study these characteristics has been reviewed (Cubells-Baeza et al., 2015). For instance, Hurley et al. (2016) used an in vitro human intestinal model system with epithelial cell lines (T84, Caco-2, and HCT-8) to evaluate potential protein hazards. Indicators of cytotoxicity (LDH release, MTT conversion), monolayer barrier integrity $([3 \mathrm{H}]$-inulin flux, horseradish peroxidase flux and transepithelial electrical resistance (TEER), and inflammation (IL-8, IL-6 release) were monitored. These authors reported that this model system effectively distinguished between hazardous and non-hazardous proteins through combined analysis of multiple cell lines and assays.

\section{Conclusions}

Alternative protein sources such as vegetables, insects and microbial proteins, can address different pillars and the goals of food security and sustainability. Their cultivation and use can contribute to preserve natural resources and biodiversity, reducing environmental damage and climate changes. Moreover, they are a source of macro and micronutrients, including high quality proteins that can be related to healthy diets and also to the prevention of diverse diseases.

As previously mentioned, HHP and electrotechnologies are recognized as environmentally friendly processes due to their high energy efficiencies and possibility to reduce the use of non-renewable resources (e.g., water and fossil energy). From the processing point of view, they bring electrical and pressure effects that can be combined with heat (if needed), offering a great versatility of processing strategies towards preservation, extraction and functional aspects of food proteins. However, the implications of these effects on the biological value of emergent food protein fractions, such as the ones related with nutritional composition, digestibility and allergenicity is far from being understood. Fundamental research is still necessary to unravel many of the potential benefits of these technologies and to develop innovative products based on alternative protein-rich fractions.

Regarding emergent proteins used as ingredients, their functionaltechnological properties are still at an exploratory level in most of the cases. While vegetable proteins were well described in the last decade, insects and microbial proteins were less explored. The effect of extraction procedures on proteins' final properties and on their aggregation and gelling mechanisms have been reported. Therefore, studies are unraveling such proteins as promising ingredients to replace conventional proteins in the food industry.

Furthermore, proteins from novel sources can be used to prepare a wide range of structures at different scales (e.g., micro and nanostructures) for bioactive compounds' delivery, which can be tailored for a specific application in innovative products, following the current "green" trend in the food industry.

Future evaluation regarding emergent proteins' fate in human gastrointestinal tract (e.g., digestion and bioavailability) is of utmost importance since reduced protein digestibility may play a role in food allergenicity. Moreover, numerous proteins have been reported to have cytotoxic or allergenic effects against human cells. Thus, more studies are needed to determine if the use of proteins from novel sources will result in more benefits than risks. Particularly, the information on nanotechnology safety exploring the use of alternative proteins remains limited or less explored and requires further risk assessment, particularly for long-term toxicity and allergenicity.

\section{Authors contribution}

The authors Luiz H. Fasolin, Ricardo N. Pereira, Joana T. Martins, Ana C. Pinheiro, Cristiane C. P. Andrade and Oscar L. Ramos contributed to conception, design, writing and revision of the manuscript. The author António A. Vicente contributed to revision of the manuscript. All authors read and approved the submitted version. 


\section{Acknowledgements}

This work was supported by the Portuguese Foundation for Science and Technology (FCT) under the scope of the strategic funding of UID/ BIO/04469/2019 and UID/Multi/50016/2019 units and BioTecNorte operation (NORTE-01-0145-FEDER-000004) funded by the European Regional Development Fund under the scope of Norte2020 - Programa Operacional Regional do Norte.

\section{References}

Aiking, H., \& de Boer, J. (2018). The next protein transition. Trends in Food Science \& Technology. https://doi.org/10.1016/j.tifs.2018.07.008 (In press).

Alu'datt, M. H., Rababah, T., \& Alli, I. (2014). Effect of phenolic compound removal on rheological, thermal and physico-chemical properties of soybean and flaxseed proteins. Food Chemistry, 146, 608-613. https://doi.org/10.1016/j.foodchem.2013.09. 104.

Ansorena, M. R., Zubeldía, F., \& Marcovich, N. E. (2016). Active wheat gluten films obtained by thermoplastic processing. LWT - Food Science and Technology, 69, 47-54. https://doi.org/10.1016/j.lwt.2016.01.020.

Arabestani, A., Kadivar, M., Shahedi, M., Goli, S. A. H., \& Porta, R. (2016). The effect of oxidized ferulic acid on physicochemical properties of bitter vetch (V icia ervilia) protein-based films. Journal of Applied Polymer Science, 133(2), https://doi.org/10. 1002/app.42894.

Ariyarathna, I. R., \& Nedra Karunaratne, D. (2015). Use of chickpea protein for encapsulation of folate to enhance nutritional potency and stability. Food and Bioproducts Processing, 95, 76-82. https://doi.org/10.1016/j.fbp.2015.04.004.

Aryee, A. N. A., \& Boye, J. I. (2016). Improving the digestibility of lentil flours and protein isolate and characterization of their enzymatically prepared hydrolysates. International Journal of Food Properties, 19(12), 2649-2665. https://doi.org/10.1080/ 10942912.2015.1123269.

Astwood, J. D., Leach, J. N., \& Fuchs, R. L. (1996). Stability of food allergens to digestion in vitro. Nature Biotechnology, 14(10), 1269-1273. https://doi.org/10.1038/nbt10961269.

Ba, F., Ursu, A. V., Laroche, C., \& Djelveh, G. (2016). Haematococcus pluvialis soluble proteins: Extraction, characterization, concentration/fractionation and emulsifying properties. Bioresource Technology, 200, 147-152. https://doi.org/10.1016/j. biortech.2015.10.012.

Bacha, U., Nasir, M., Khalique, A., Anjum, A. A., \& Jabbar, M. A. (2011). Comparative assessment of various agro-industrial wastes for saccharomyces cerevisiae biomass production and its quality evaluation as single cell protein. The Journal of Animal \& Plant Sciences, 21(4), 844-849.

Bähr, M., Fechner, A., Hasenkopf, K., Mittermaier, S., \& Jahreis, G. (2014). Chemical composition of dehulled seeds of selected lupin cultivars in comparison to pea and soya bean. LWT - Food Science and Technology, 59(1), 587-590. https://doi.org/10. 1016/j.lwt.2014.05.026.

Bai, K.-C., \& Sheu, F. (2018). A novel protein from edible fungi Cordyceps militaris that induces apoptosis. Journal of Food and Drug Analysis, 26(1), 21-30. https://doi.org/ 10.1016/j.jfda.2016.10.013.

Bao, C., Jiang, P., Chai, J., Jiang, Y., Li, D., Bao, W., ... Li, Y. (2019). The delivery of sensitive food bioactive ingredients: Absorption mechanisms, influencing factors, encapsulation techniques and evaluation models. Food Research International, 120, 130-140. https://doi.org/10.1016/j.foodres.2019.02.024.

Barba, F. J., Parniakov, O., Pereira, S. A., Wiktor, A., Grimi, N., Boussetta, N., ... Vorobiev, E. (2015). Current applications and new opportunities for the use of pulsed electric fields in food science and industry. Food Research International, 77, 773-798. https:// doi.org/10.1016/j.foodres.2015.09.015.

Becker, E. W. (2007). Micro-algae as a source of protein. Biotechnology Advances, 25(2), 207-210. https://doi.org/10.1016/j.biotechadv.2006.11.002.

Beltrán-Barrientos, L. M., García, H. S., Torres-Llanez, M. J., González-Córdova, A. F., Hernández-Mendoza, A., \& Vallejo-Cordoba, B. (2017). Safety of milk-derived bioactive peptides. International Journal of Dairy Technology, 70(1), 16-22. https:// doi.org/10.1111/1471-0307.12338.

Benelhadj, S., Gharsallaoui, A., Degraeve, P., Attia, H., \& Ghorbel, D. (2016). Effect of pH on the functional properties of Arthrospira (spirulina) platensis protein isolate. Food Chemistry, 194, 1056-1063. https://doi.org/10.1016/j.foodchem.2015.08.133.

Berghout, J. A. M., Boom, R. M., \& van der Goot, A. J. (2015). Understanding the differences in gelling properties between lupin protein isolate and soy protein isolate. Food Hydrocolloids, 43, 465-472. https://doi.org/10.1016/j.foodhyd.2014.07.003.

Burgos-Díaz, C., Gallardo, M., Morales, E., Piornos, J. A., Marqués, A. M., \& Rubilar, M. (2016). Utilization of proteins from Alu Prot -CGNA (a novel protein-rich lupin variety) in the development of oil-in-water multilayer emulsion systems. European Journal of Lipid Science and Technology, 118(7), 1104-1112. https://doi.org/10.1002/ ejlt.201500260.

Burgos-Díaz, C., Hernández, X., Wandersleben, T., Barahona, T., Medina, C., Quiroz, A., \& Rubilar, M. (2018). Influence of multilayer O/W emulsions stabilized by proteins from a novel lupin variety AluProt-CGNA and ionic polysaccharides on d -limonene retention during spray-drying. Colloids and Surfaces A: Physicochemical and Engineering Aspects, 536, 234-241. https://doi.org/10.1016/j.colsurfa.2017.04.032.

Burgos-Díaz, C., Piornos, J. A., Wandersleben, T., Ogura, T., Hernández, X., \& Rubilar, M. (2016). Emulsifying and foaming properties of different protein fractions obtained from a novel Lupin variety Alu Prot -CGNA ${ }^{\oplus}$ (Lupinus luteus). Journal of Food Science, 81(7), C1699-C1706. https://doi.org/10.1111/1750-3841.13350.

Burgos-Díaz, C., Wandersleben, T., Marqués, A. M., \& Rubilar, M. (2016). Multilayer emulsions stabilized by vegetable proteins and polysaccharides. Current Opinion in Colloid \& Interface Science, 25, 51-57. https://doi.org/10.1016/j.cocis.2016.06.014.
Busnelli, M., Manzini, S., Sirtori, C., Chiesa, G., \& Parolini, C. (2018). Effects of vegetable proteins on hypercholesterolemia and gut microbiota modulation. Nutrients, 10(9), E1249. https://doi.org/10.3390/nu10091249.

Can Karaca, A., Nickerson, M. T., \& Low, N. H. (2011). Lentil and chickpea proteinstabilized emulsions: Optimization of emulsion formulation. Journal of Agricultural and Food Chemistry, 59(24), 13203-13211. https://doi.org/10.1021/jf203028n.

Canistro, D., Vivarelli, F., Ugolini, L., Pinna, C., Grandi, M., Antonazzo, I. C., ... Biagi, G. (2017). Digestibility, toxicity and metabolic effects of rapeseed and sunflower protein hydrolysates in mice. Italian Journal of Animal Science, 16(3), 462-473. https://doi. org/10.1080/1828051X.2017.1298410.

Cappato, L. P., Ferreira, M. V. S., Guimaraes, J. T., Portela, J. B., Costa, A. L. R., Freitas, M. Q., ... Cruz, A. G. (2017). Ohmic heating in dairy processing: Relevant aspects for safety and quality. Trends in Food Science \& Technology, 62, 104-112. https://doi.org/ 10.1016/j.tifs.2017.01.010.

del Carmen Vasallo, M., Puppo, M. C., Palazolo, G. G., Otero, M. A., Beress, L., \& Wagner, J. R. (2006). Cell wall proteins of Kluyveromyces fragilis: Surface and emulsifying properties. LWT - Food Science and Technology, 39(7), 729-739. https://doi.org/10. 1016/j.lwt.2005.06.003.

Caselato-Sousa, V. M., \& Amaya-Farfán, J. (2012). State of knowledge on Amaranth grain: A comprehensive review. Journal of Food Science, 77(4), R93-R104. https://doi.org/ 10.1111/j.1750-3841.2012.02645.x.

de Castro, R. J. S., Ohara, A., Aguilar, J. G. D. S., \& Domingues, M. A. F. (2018). Nutritional, functional and biological properties of insect proteins: Processes for obtaining, consumption and future challenges. Trends in Food Science \& Technology, 76, 82-89. https://doi.org/10.1016/j.tifs.2018.04.006.

Cerqueira, M. A., Pinheiro, A. C., Ramos, O. L., Silva, H., Bourbon, A. I., \& Vicente, A. A. (2017). Advances in food nanotechnology. In R. Busquets (Ed.). Emerging nanotechnologies in food science (pp. 11-38). (1st ed.). . https://doi.org/10.1016/B978-0323-42980-1.00002-9.

Cerqueira, M. A., Pinheiro, A. C., Silva, H. D., Ramos, P. E., Azevedo, M. A., Flores-López, M. L., ... Vicente, A. A. (2014). Design of bio-nanosystems for oral delivery of functional compounds. Food Engineering Reviews, 6(1-2), 1-19. https://doi.org/10.1007/ s12393-013-9074-3.

Chalamaiah, M., Hemalatha, R., Jyothirmayi, T., Diwan, P. V., Bhaskarachary, K., Vajreswari, A., ... Dinesh Kumar, B. (2015). Chemical composition and immunomodulatory effects of enzymatic protein hydrolysates from common carp (Cyprinus carpio) egg. Nutrition, 31(2), 388-398. https://doi.org/10.1016/j.nut 2014.08.006.

Chalamaiah, M., Jyothirmayi, T., Diwan, P. V., \& Dinesh Kumar, B. (2015). Antiproliferative, ACE-inhibitory and functional properties of protein hydrolysates from rohu (Labeo rohita) roe (egg) prepared by gastrointestinal proteases. Journal of Food Science and Technology, 52(12), 8300-8307. https://doi.org/10.1007/s13197015-1969-y.

Chalamaiah, M., Yu, W., \& Wu, J. (2018). Immunomodulatory and anticancer protein hydrolysates (peptides) from food proteins: A review. Food Chemistry, 245, 205-222. https://doi.org/10.1016/j.foodchem.2017.10.087.

Chandra, R., Iqbal, H. M. N., Vishal, G., Lee, H.-S., \& Nagra, S. (2019). Algal biorefinery: A sustainable approach to valorize algal-based biomass towards multiple product recovery. Bioresource Technology, 278, 346-359. https://doi.org/10.1016/j.biortech. 2019.01.104.

Chardigny, J.-M., \& Walrand, S. (2016). Plant protein for food: Opportunities and bottlenecks. OCL Oilseeds and Fats Crops and Lipids, 23(4), D404. https://doi.org/10. $1051 / 0 \mathrm{cl} / 2016019$.

Chizoba Ekezie, F.-G., Cheng, J.-H., \& Sun, D.-W. (2018). Effects of nonthermal food processing technologies on food allergens: A review of recent research advances. Trends in Food Science \& Technology, 74, 12-25. https://doi.org/10.1016/j.tifs.2018. 01.007.

Chronakis, I. S. (2001). Gelation of edible blue-green algae protein isolate (spirulina platensis strain pacifica): Thermal transitions, rheological properties, and molecular forces involved. Journal of Agricultural and Food Chemistry, 49(2), 888-898. https:// doi.org/10.1021/jf0005059.

Chronakis, I. S., Galatanu, A. N., Nylander, T., \& Lindman, B. (2000). The behaviour of protein preparations from blue-green algae (Spirulina platensis strain Pacifica) at the air/water interface. Colloids and Surfaces A: Physicochemical and Engineering Aspects, 173(1-3), 181-192. https://doi.org/10.1016/S0927-7757(00)00548-3.

Costa, A. M. M., Nunes, J. C., Lima, B. N., Pedrosa, C., Calado, V., Torres, A. G., \& Pierucci, A. P. T. R. (2015). Effective stabilization of CLA by microencapsulation in pea protein. Food Chemistry, 168, 157-166. https://doi.org/10.1016/j.foodchem. 2014.07.016.

Crevel, R. W. R., Baumert, J. L., Baka, A., Houben, G. F., Knulst, A. C., Kruizinga, A. G., .. Madsen, C. B. (2014). Development and evolution of risk assessment for food allergens. Food and Chemical Toxicology, 67, 262-276. https://doi.org/10.1016/j.fct. 2014.01.032.

Cubells-Baeza, N., Verhoeckx, K. C. M., Larre, C., Denery-Papini, S., Gavrovic-Jankulovic, M., \& Diaz Perales, A. (2015). Applicability of epithelial models in protein permeability/transport studies and food allergy. Drug Discovery Today: Disease Models, 17-18, 13-21. https://doi.org/10.1016/j.ddmod.2016.08.002.

Czubiński, J., Siger, A., \& Lampart-Szczapa, E. (2016). Digestion susceptibility of seed globulins isolated from different lupin species. European Food Research and Technology, 242(3), 391-403. https://doi.org/10.1007/s00217-015-2550-7.

Day, L. (2013). Proteins from land plants - Potential resources for human nutrition and food security. Trends in Food Science \& Technology, 32(1), 25-42. https://doi.org/10. 1016/j.tifs.2013.05.005.

De Maria, S., Ferrari, G., \& Maresca, P. (2016). Effects of high hydrostatic pressure on the conformational structure and the functional properties of bovine serum albumin. Innovative Food Science and Emerging Technologies. https://doi.org/10.1016/j.ifset. 2015.11.025.

De Vries, H., Mikolajczak, M., Salmon, J.-M., Abecassis, J., Chaunier, L., Guessasma, S., .. Trystram, G. (2018). Small-scale food process engineering - Challenges and perspectives. Innovative Food Science \& Emerging Technologies, 46, 122-130. https://doi. 
$\operatorname{org} / 10.1016 /$ j.ifset.2017.09.009.

Denavi, G. A., Pérez-Mateos, M., Añón, M. C., Montero, P., Mauri, A. N., \& Gómez-Guillén, M. C. (2009). Structural and functional properties of soy protein isolate and cod gelatin blend films. Food Hydrocolloids, 23(8), 2094-2101. https://doi.org/10.1016/ j.foodhyd.2009.03.007.

Djoullah, A., Husson, F., \& Saurel, R. (2018). Gelation behaviors of denaturated pea albumin and globulin fractions during transglutaminase treatment. Food Hydrocolloids, 77, 636-645. https://doi.org/10.1016/j.foodhyd.2017.11.005.

Duda, A., Adamczak, J., Chełmińska, P., Juszkiewicz, J., \& Kowalczewski, P. (2019). Quality and nutritional/textural properties of durum wheat pasta enriched with cricket powder. Foods, 8(2), 46. https://doi.org/10.3390/foods8020046.

Durán, N., \& Marcato, P. D. (2013). Nanobiotechnology perspectives. Role of nanotechnology in the food industry: A review. International Journal of Food Science \& Technology, 48(6), 1127-1134. https://doi.org/10.1111/ijfs.12027.

Elzoghby, A. O., Samy, W. M., \& Elgindy, N. A. (2012). Protein-based nanocarriers as promising drug and gene delivery systems. Journal of Controlled Release, 161(1), 38-49. https://doi.org/10.1016/j.jconrel.2012.04.036.

FAO (2010). Sustainable diets and biodiversity - directions and solutions for policy, research and action. Proceedings of the international scientific symposium biodiversity and sustainable diets united against hunger. Rome.

FAO (2011). World livestock 2011 - Livestock in food security world. In Rome, FAOhttps:// doi.org/10.1080/00036841003742587.

FAO (2014). Conference outcome document: Framework for action. Second international conference on nutrition. https://doi.org/10.1044/leader.PPL.19102014.18.

FAO (2017). The future of food and agriculture - Trends and challenges. In Rome, FAOhttps://doi.org/10.4161/chan.4.6.12871.

FAO/WHO (2007). Protein and aminoa cid requirement in human nutrition. World Health Organization (https://doi.org/ISBN 924120935 6).

Felix, M., Cermeño, M., Romero, A., \& FitzGerald, R. J. (2019). Characterisation of the bioactive properties and microstructure of chickpea protein-based oil in water emulsions. Food Research International, 121, 577-585. https://doi.org/10.1016/j. foodres.2018.12.022.

Fernandez, A., Mills, E. N. C., Koning, F., \& Moreno, F. J. (2019). Safety assessment of immune-mediated adverse reactions to novel food proteins. Trends in Biotechnology, 37(8), 796-800. https://doi.org/10.1016/j.tibtech.2019.03.010.

Fu, T.-J., Abbott, U. R., \& Hatzos, C. (2002). Digestibility of food allergens and nonallergenic proteins in simulated gastric fluid and simulated intestinal fluid a comparative study. Journal of Agricultural and Food Chemistry, 50(24), 7154-7160. https://doi.org/10.1021/jf020599h.

Gahukar, R. T. (2016). Edible insects farming: Efficiency and impact on family livelihood, food security, and environment compared with livestock and crops. In A. T. Dossey, J. A. Morales-Ramos, \& M. G. Rojas (Eds.). Insects as sustainable food ingredients (pp. 85111). . https://doi.org/10.1016/B978-0-12-802856-8.00004-1.

Gamazo, C., Gastaminza, G., Ferrer, M., Sanz, M. L., \& Irache3, J. M. (2014). Nanoparticle based-immunotherapy against allergy. Immunotherapy, 6(7), 885-897.

Gerde, J. A., Wang, T., Yao, L., Jung, S., Johnson, L. A., \& Lamsal, B. (2013). Optimizing protein isolation from defatted and non-defatted nannochloropsis microalgae biomass. Algal Research, 2(2), 145-153. https://doi.org/10.1016/j. algal.2013.02.001.

Gervasi, T., Pellizzeri, V., Calabrese, G., Di Bella, G., Cicero, N., \& Dugo, G. (2018). Production of single cell protein (SCP) from food and agricultural waste by using Saccharomyces cerevisiae. Natural Product Research, 32(6), 648-653. https://doi.org/ 10.1080/14786419.2017.1332617.

Goldberg, I. (1985). Single cell protein. https://doi.org/10.1007/978-3-642-46540-6.

González-Montoya, M., Hernández-Ledesma, B., Silván, J. M., Mora-Escobedo, R., \& Martínez-Villaluenga, C. (2018). Peptides derived from in vitro gastrointestinal digestion of germinated soybean proteins inhibit human colon cancer cells proliferation and inflammation. Food Chemistry, 242, 75-82. https://doi.org/10.1016/j.foodchem. 2017.09.035.

van der Goot, A. J., Pelgrom, P. J. M., Berghout, J. A. M., Geerts, M. E. J., Jankowiak, L., Hardt, N. A., ... Boom, R. M. (2016). Concepts for further sustainable production of foods. Journal of Food Engineering, 168, 42-51. https://doi.org/10.1016/j.jfoodeng. 2015.07.010.

Gould, J., \& Wolf, B. (2018). Interfacial and emulsifying properties of mealworm protein at the oil/water interface. Food Hydrocolloids. https://doi.org/10.1016/j.foodhyd. 2017.09.018.

Groell, F., Jordan, O., \& Borchard, G. (2018). In vitro models for immunogenicity prediction of therapeutic proteins. European Journal of Pharmaceutics and Biopharmaceutics, 130, 128-142. https://doi.org/10.1016/j.ejpb.2018.06.008.

Guiné, R. P. F., Ramalhosa, E. C. D., \& Valente, P. L. (2016). New foods, new consumers: Innovation in food product development. Current Nutrition \& Food Science, 12(3), 175-189. https://doi.org/10.2174/1573401312666160608120727.

Hall, F. G., Jones, O. G., O'Haire, M. E., \& Liceaga, A. M. (2017). Functional properties of tropical banded cricket (Gryllodes sigillatus) protein hydrolysates. Food Chemistry, 224, 414-422. https://doi.org/10.1016/j.foodchem.2016.11.138.

Hartmann, C., \& Siegrist, M. (2016). Becoming an insectivore: Results of an experiment. Food Quality and Preference, 51, 118-122. https://doi.org/10.1016/j.foodqual.2016. 03.003.

Henchion, M., Hayes, M., Mullen, A., Fenelon, M., \& Tiwari, B. (2017). Future protein supply and demand: Strategies and factors influencing a sustainable equilibrium. Foods, 6(7), E53. https://doi.org/10.3390/foods6070053.

Hosseini, S. M., \& Khosravi-Darani, K. (2011). Response surface methodology for mycoprotein production by fusarium Venenatum ATCC 20334. Journal of Bioprocessing \& Biotechniques, 01(01), https://doi.org/10.4172/2155-9821.1000102.

Hu, K., \& McClements, D. J. (2015). Fabrication of biopolymer nanoparticles by antisolvent precipitation and electrostatic deposition: Zein-alginate core/shell nanoparticles. Food Hydrocolloids, 44, 101-108. https://doi.org/10.1016/j.foodhyd.2014. 09.015.

Huc-Mathis, D., Journet, C., Fayolle, N., \& Bosc, V. (2019). Emulsifying properties of food by-products: Valorizing apple pomace and oat bran. Colloids and Surfaces A: Physicochemical and Engineering Aspects, 568, 84-91. https://doi.org/10.1016/j. colsurfa.2019.02.001

van Huis, A. (2013). Potential of insects as food and feed in assuring food security. Annua Review of Entomology, 58(1), 563-583. https://doi.org/10.1146/annurev-ento120811-153704.

van Huis, A. (2016). Edible insects are the future? Proceedings of the Nutrition Society, 75(03), 294-305. https://doi.org/10.1017/S0029665116000069.

Hurley, B. P., Pirzai, W., Eaton, A. D., Harper, M., Roper, J., Zimmermann, C., ... Delaney, B. (2016). An experimental platform using human intestinal epithelial cell lines to differentiate between hazardous and non-hazardous proteins. Food and Chemical Toxicology, 92, 75-87. https://doi.org/10.1016/j.fct.2016.04.003.

Jaeger, H., Roth, A., Toepfl, S., Holzhauser, T., Engel, K.-H., Knorr, D., ... Steinberg, P. (2016). Opinion on the use of ohmic heating for the treatment of foods. Trends in Food Science \& Technology, 55, 84-97. https://doi.org/10.1016/j.tifs.2016.07.007.

Jansen-Alves, C., Maia, D. S. V., Krumreich, F. D., Crizel-Cardoso, M. M., Fioravante, J. B. da Silva, W. P., ... Zambiazi, R. C. (2019). Propolis microparticles produced with pea protein: Characterization and evaluation of antioxidant and antimicrobial activities. Food Hydrocolloids, 87, 703-711. https://doi.org/10.1016/j.foodhyd.2018.09.004.

Janssen, R. H., Vincken, J.-P., van den Broek, L. A. M., Fogliano, V., \& Lakemond, C. M. M. (2017). Nitrogen-to-protein conversion factors for three edible insects: Tenebrio molitor, alphitobius diaperinus, and hermetia illucens. Journal of Agricultural and Food Chemistry, 65(11), 2275-2278. https://doi.org/10.1021/acs.jafc.7b00471.

Jiang, J., Zhu, B., Liu, Y., \& Xiong, Y. L. (2014). Interfacial structural role of pH-shifting processed pea protein in the oxidative stability of oil/water emulsions. Journal of Agricultural and Food Chemistry, 62(7), 1683-1691. https://doi.org/10.1021/ jf405190h.

Jonas-Levi, A., \& Martinez, J. J. I. (2017). The high level of protein content reported in insects for food and feed is overestimated. Journal of Food Composition and Analysis. https://doi.org/10.1016/j.jfca.2017.06.004.

Jones, O. G. (2016). Recent advances in the functionality of non-animal-sourced proteins contributing to their use in meat analogs. Current Opinion in Food Science, 7, 7-13. https://doi.org/10.1016/j.cofs.2015.08.002.

Jongema, Y. (2017). List of edible insects of the world. (April 1, 2017).

Joyce, A., Dixon, S., Comfort, J., \& Hallett, J. (2012). Reducing the environmental impact of dietary choice: Perspectives from a behavioural and social change approach. Journal of Environmental and Public Health, 2012, 1-7. https://doi.org/10.1155/ 2012/978672.

Kamal, M. M., Ali, M. R., Shishir, M. R. I., Saifullah, M., Haque, M. R., \& Mondal, S. C. (2019). Optimization of process parameters for improved production of biomass protein from aspergillus Niger using banana peel as a substrate. Food Science and Biotechnology.. https://doi.org/10.1007/s10068-019-00636-2.

Kang, K.-H., Qian, Z.-J., Ryu, B., Kim, D., \& Kim, S.-K. (2012). Protective effects of protein hydrolysate from marine microalgae Navicula incerta on ethanol-induced toxicity in HepG2/CYP2E1 cells. Food Chemistry, 132(2), 677-685. https://doi.org/10.1016/j. foodchem.2011.10.031.

Kasaai, M. R. (2018). Zein and zein -based nano-materials for food and nutrition applications: A review. Trends in Food Science \& Technology, 79, 184-197. https://doi.org/ 10.1016/j.tifs.2018.07.015.

Knirsch, M. C., Alves dos Santos, C., Vicente, A. A., \& Penna, T. C. V. (2010). Ohmic heating - A review. Trends in Food Science \& Technology, 21(9), 436-441. https://doi. org/10.1016/j.tifs.2010.06.003.

Kojima, G., Avgerinou, C., Iliffe, S., Jivraj, S., Sekiguchi, K., \& Walters, K. (2018). Fruit and vegetable consumption and frailty: A systematic review. The Journal of Nutrition, Health \& Aging, 22(8), 1010-1017. https://doi.org/10.1007/s12603-018-1069-6.

Kouřimská, L., \& Adámková, A. (2016). Nutritional and sensory quality of edible insects. NFS Journal, 4, 22-26. https://doi.org/10.1016/j.nfs.2016.07.001.

Kulma, M., Kouřimská, L., Plachý, V., Božik, M., Adámková, A., \& Vrabec, V. (2019). Effect of sex on the nutritional value of house cricket, Acheta domestica L. Food Chemistry. https://doi.org/10.1016/j.foodchem.2018.08.049.

Kurcz, A., Błażejak, S., Kot, A. M., Bzducha-Wróbel, A., \& Kieliszek, M. (2018). Application of industrial wastes for the production of microbial single-cell protein by fodder yeast candida utilis. Waste and Biomass Valorization, 9(1), 57-64. https://doi. org/10.1007/s12649-016-9782-z.

Ladjal Ettoumi, Y., Chibane, M., \& Romero, A. (2016). Emulsifying properties of legume proteins at acidic conditions: Effect of protein concentration and ionic strength. $L W T$. Food Science and Technology, 66, 260-266. https://doi.org/10.1016/j.lwt.2015.10 051.

Laguna, L., Picouet, P., Guàrdia, M. D., Renard, C. M. G. C., \& Sarkar, A. (2017). In vitro gastrointestinal digestion of pea protein isolate as a function of $\mathrm{pH}$, food matrices, autoclaving, high-pressure and re-heat treatments. LWT, 84, 511-519. https://doi. org/10.1016/j.lwt.2017.06.021.

Lam, A. C. Y., Can Karaca, A., Tyler, R. T., \& Nickerson, M. T. (2018). Pea protein isolates: Structure, extraction, and functionality. Food Reviews International, 34(2), 126-147. https://doi.org/10.1080/87559129.2016.1242135.

Lamsal, B., Wang, H., Pinsirodom, P., \& Dossey, A. T. (2019). Applications of insectderived protein ingredients in food and feed industry. Journal of the American Oil Chemists' Society, 96(2), 105-123. https://doi.org/10.1002/aocs.12180.

Laurens, L. M. L., Markham, J., Templeton, D. W., Christensen, E. D., Van Wychen, S., Vadelius, E. W., ... Pienkos, P. T. (2017). Development of algae biorefinery concept for biofuels and bioproducts; a perspective on process-compatible products and their impact on cost-reduction. Energy \& Environmental Science, 10(8), 1716-1738. https:// doi.org/10.1039/C7EE01306J.

Lensvelt, E. J. S., \& Steenbekkers, L. P. A. (2014). Exploring consumer acceptance of entomophagy: A survey and experiment in Australia and the Netherlands. Ecology of Food and Nutrition, 53(5), 543-561. https://doi.org/10.1080/03670244.2013. 879865.

Li, H., Wang, D., Liu, C., Zhu, J., Fan, M., Sun, X., ... Cao, Y. (2019). Fabrication of stable zein nanoparticles coated with soluble soybean polysaccharide for encapsulation of quercetin. Food Hydrocolloids, 87, 342-351. https://doi.org/10.1016/j.foodhyd. 2018.08 .002$.

Li, H., Zhu, K., Zhou, H., \& Peng, W. (2012). Effects of high hydrostatic pressure treatment 
on allergenicity and structural properties of soybean protein isolate for infant formula. Food Chemistry, 132(2), 808-814. https://doi.org/10.1016/j.foodchem.2011. 11.040.

Li, H., Zhu, K., Zhou, H., Peng, W., \& Guo, X. (2016). Comparative study of four physical approaches about allergenicity of soybean protein isolate for infant formula. Food and Agricultural Immunology, 27(5), 604-623. https://doi.org/10.1080/09540105.2015. 1129602.

Li, J., \& Karboune, S. (2019). Characterization of the composition and the techno-func tional properties of mannoproteins from Saccharomyces cerevisiae yeast cell walls. Food Chemistry, 297, 124867. https://doi.org/10.1016/j.foodchem.2019.05.141.

Liao, Z., Ye, Y., Wang, H., Chen, Y., Sha, X., Zhang, L., ... Tu, Z. (2018). The mechanism of decreased IgG/IgE-binding of ovalbumin by preheating treatment combined with glycation identified by liquid chromatography and high-resolution mass spectrometry. Journal of Agricultural and Food Chemistry, 66(41), 10693-10702. https://doi. org/10.1021/acs.jafc.8b04165.

Liu, C. M., Peng, Q., Zhong, J. Z., Liu, W., Zhong, Y. J., \& Wang, F. (2018). Molecular and functional properties of protein fractions and isolate from cashew nut (Anacardium occidentale L.). Molecules, 23(2), E393. https://doi.org/10.3390/ molecules23020393.

Lonnie, M., Hooker, E., Brunstrom, J., Corfe, B., Green, M., Watson, A., ... Johnstone, A. (2018). Protein for life: Review of optimal protein intake, sustainable dietary sources and the effect on appetite in ageing adults. Nutrients, 10(3), E360. https://doi.org/10. 3390/nu10030360.

López, D. N., Ingrassia, R., Busti, P., Wagner, J., Boeris, V., \& Spelzini, D. (2018). Effects of extraction $\mathrm{pH}$ of chia protein isolates on functional properties. LWT, 97, 523-529. https://doi.org/10.1016/j.lwt.2018.07.036.

Loveday, S. M. (2019). Food proteins: Technological, nutritional, and sustainability attributes of traditional and emerging proteins. Annual Review of Food Science and Technology, 10(1), 311-339. https://doi.org/10.1146/annurev-food-032818-121128.

Lynch, H., Johnston, C., \& Wharton, C. (2018). Plant-based diets: Considerations for environmental impact, protein quality, and exercise performance. Nutrients, 10(12), E1841. https://doi.org/10.3390/nu10121841.

Machado, L. F., Pereira, R. N., Martins, R. C., Teixeira, J. A., \& Vicente, A. A. (2010). Moderate electric fields can inactivate Escherichia coli at room temperature. Journal of Food Engineering, 96(4), 520-527. https://doi.org/10.1016/j.jfoodeng.2009.08. 035.

Madalena, D. A., Pereira, R. N., Vicente, A. A., Ramos, Ó. L., Melton, L., Shahidi, F., \& Varelis, P. (2019). New insights on bio-based micro- and nanosystems in food. Encyclopedia of food chemistry (pp. 708-714). . https://doi.org/10.1016/B978-0-08100596-5.21859-3.

Madalena, D. A., Ramos, Ó. L., Pereira, R. N., Bourbon, A. I., Pinheiro, A. C., Malcata, F. X., ... Vicente, A. A. (2016). In vitro digestion and stability assessment of $\beta$-lactoglobulin/riboflavin nanostructures. Food Hydrocolloids, 58, 89-97. https://doi.org/ 10.1016/j.foodhyd.2016.02.015

Makri, E., Papalamprou, E., \& Doxastakis, G. (2005). Study of functional properties of seed storage proteins from indigenous European legume crops (lupin, pea, broad bean) in admixture with polysaccharides. Food Hydrocolloids, 19(3), 583-594. https://doi.org/10.1016/j.foodhyd.2004.10.028.

Malik, V. S., Li, Y., Tobias, D. K., Pan, A., \& Hu, F. B. (2016). Dietary protein intake and risk of type 2 diabetes in US men and women. American Journal of Epidemiology, 183(8), 715-728. https://doi.org/10.1093/aje/kwv268.

López-Pedrouso, M., Díaz-Reinoso, B., Lorenzo, J. M., Cravotto, G., Barba, F. J., Moure, A., Domínguez, H., \& Franco, D. (2019). Green technologies for food processing: Principal considerations. In F. J. Barba, J. M. A. Saraiva, G. Cravotto, \& J. M. Lorenzo (Eds.). Innovative thermal and non-thermal processing, bioaccessibility and bioavailability of nutrients and bioactive compounds (pp. 55-103). . https://doi.org/10.1016/B978-012-814174-8.00003-2.

Matassa, S., Boon, N., Pikaar, I., \& Verstraete, W. (2016). Microbial protein: Future sustainable food supply route with low environmental footprint. Microbial Biotechnology, 9(5), 568-575. https://doi.org/10.1111/1751-7915.12369.

Matsuo, H., Yokooji, T., \& Taogoshi, T. (2015). Common food allergens and their IgEbinding epitopes. Allergology International, 64(4), 332-343. https://doi.org/10.1016/ j.alit.2015.06.009.

Mazzucchelli, G., Holzhauser, T., Cirkovic Velickovic, T., Diaz-Perales, A., Molina, E., Roncada, P., ... Hoffmann-Sommergruber, K. (2018). Current (food) allergenic risk assessment: Is it fit for novel foods? Status quo and identification of gaps. Molecular Nutrition \& Food Research, 62(1), 1700278. https://doi.org/10.1002/mnfr. 201700278.

Melina, V., Craig, W., \& Levin, S. (2016). Position of the academy of nutrition and dietetics: Vegetarian diets. Journal of the Academy of Nutrition and Dietetics, 116(12), 1970-1980. https://doi.org/10.1016/j.jand.2016.09.025.

Meng, X., Bai, Y., Gao, J., Li, X., \& Chen, H. (2017). Effects of high hydrostatic pressure on the structure and potential allergenicity of the major allergen bovine $\beta$-lactoglobulin. Food Chemistry, 219, 290-296. https://doi.org/10.1016/j.foodchem.2016.09.153.

Miglietta, P., De Leo, F., Ruberti, M., \& Massari, S. (2015). Mealworms for food: A water footprint perspective. Water, 7(11), 6190-6203. https://doi.org/10.3390/w7116190.

Mishyna, M., Martinez, J.-J. I., Chen, J., \& Benjamin, O. (2019). Extraction, characterization and functional properties of soluble proteins from edible grasshopper (Schistocerca gregaria) and honey bee (Apis mellifera). Food Research International, 116, 697-706. https://doi.org/10.1016/j.foodres.2018.08.098.

Mishyna, M., Martinez, J.-J. I., Chen, J., Davidovich-Pinhas, M., \& Benjamin, O. (2019). Heat-induced aggregation and gelation of proteins from edible honey bee brood (Apis mellifera) as a function of temperature and pH. Food Hydrocolloids, 91, 117-126. https://doi.org/10.1016/j.foodhyd.2019.01.017.

Mokni Ghribi, A., Maklouf Gafsi, I., Sila, A., Blecker, C., Danthine, S., Attia, H., ... Besbes, S. (2015). Effects of enzymatic hydrolysis on conformational and functional properties of chickpea protein isolate. Food Chemistry, 187, 322-330. https://doi.org/10. 1016/j.foodchem.2015.04.109.

Monteiro, A. A., Monteiro, M. R., Pereira, R. N., Diniz, R., Costa, A. R., Malcata, F. X., Ramos, Ó. L. (2016). Design of bio-based supramolecular structures through self- assembly of $\alpha$-lactalbumin and lysozyme. Food Hydrocolloids, 58, 60-74. https://doi. org/10.1016/j.foodhyd.2016.02.009.

Monteiro, S. R., \& Lopes-da-Silva, J. A. (2019). Critical evaluation of the functionality of soy protein isolates obtained from different raw materials. European Food Research and Technology, 245(1), 199-212. https://doi.org/10.1007/s00217-018-3153-x.

Msambichaka, B., Eze, I. C., Abdul, R., Abdulla, S., Klatser, P., Tanner, M., ... Geubbels, E. (2018). Insufficient fruit and vegetable intake in a low- and middle-income setting: A population-based survey in semi-urban Tanzania. Nutrients, 10(2), 222. https://doi. org/10.3390/nu10020222.

Mwangi, M. N., Oonincx, D. G. A. B., Stouten, T., Veenenbos, M., Melse-Boonstra, A., Dicke, M., \& van Loon, J. J. A. (2018). Insects as sources of iron and zinc in human nutrition. Nutrition Research Reviews, 31(2), 248-255. https://doi.org/10.1017/ S0954422418000094.

Nadathur, S. R., Wanasundara, J. P., \& Scanlin, L. (2017). Proteins in the diet: Challenges in feeding the global population. In S. R. Nadathur, J. P. D. Wanasundara, \& L. Scanlin (Eds.). Sustainable protein sources (pp. 1-19). . https://doi.org/10.1016/B9780-12-802778-3.00001-9.

Nieto-Nieto, T. V., Wang, Y. X., Ozimek, L., \& Chen, L. (2014). Effects of partial hydrolysis on structure and gelling properties of oat globular proteins. Food Research International, 55, 418-425. https://doi.org/10.1016/j.foodres.2013.11.038.

Niva, M., Vainio, A., \& Jallinoja, P. (2017). Barriers to increasing plant protein consumption in western populations. In F. Mariotti (Ed.). Vegetarian and plant-based diets in health and disease prevention (pp. 157-171). . https://doi.org/10.1016/B978-0-12803968-7.00010-1.

Oonincx, D. G. A. B. (2017). Environmental impact of insect production. In A. van Huis, \& J. K. Tomberlin (Eds.). Insects as food and feed: From production to consumption (pp. 79-93). Wageningen: Wageningen Academic Publishers.

Osimani, A., Milanović, V., Cardinali, F., Roncolini, A., Garofalo, C., Clementi, F., .. Aquilanti, L. (2018). Bread enriched with cricket powder (Acheta domesticus): A technological, microbiological and nutritional evaluation. Innovative Food Science \& Emerging Technologies, 48, 150-163. https://doi.org/10.1016/j.ifset.2018.06.007.

Otero, M. A., Guerrero, I., Wagner, J. R., Cabello, A. J., Sceni, P., Garciá, R., ... Almazań, O. (2011). Yeast and its derivatives as ingredients in the food industry. Biotecnologia Aplicada, 28(4), 272-275.

Otero, M. A., Wagner, J. R., Vasallo, M. C., \& García, L., \& Añón, M. C. (2000). Thermal behavior and hydration properties of yeast proteins from Saccharomyces cerevisiae and Kluyveromyces fragilis. Food Chemistry, 69(2), 161-165. https://doi.org/10. 1016/S0308-8146(99)00245-9.

Pali-Schöll, I., Verhoeckx, K., Mafra, I., Bavaro, S. L., Clare Mills, E. N., \& Monaci, L. (2019). Allergenic and novel food proteins: State of the art and challenges in the allergenicity assessment. Trends in Food Science \& Technology, 84, 45-48. https://doi. org/10.1016/j.tifs.2018.03.007.

Panda, R., Tetteh, A. O., Pramod, S. N., \& Goodman, R. E. (2015). Enzymatic hydrolysis does not reduce the biological reactivity of soybean proteins for all allergic subjects. Journal of Agricultural and Food Chemistry, 63(43), 9629-9639. https://doi.org/10. 1021/acs.jafc.5b02927.

Parenti, M. D., Santoro, A., Del Rio, A., \& Franceschi, C. (2019). Literature review in support of adjuvanticity/immunogenicity assessment of proteins. EFSA Supporting Publications, 16(1), https://doi.org/10.2903/sp.efsa.2019.EN-1551.

Pataro, G., Barca, G. M. J., Pereira, R. N., Vicente, A. A., Teixeira, J. A., \& Ferrari, G. (2014). Quantification of metal release from stainless steel electrodes during conventional and pulsed ohmic heating. Innovative Food Science \& Emerging Technologies, 21, 66-73. https://doi.org/10.1016/j.ifset.2013.11.009.

Patel, A., Hu, Y., Tiwari, J. K., \& Velikov, K. P. (2010). Synthesis and characterisation of zein-curcumin colloidal particles. Soft Matter, 6(24), 6192. https://doi.org/10.1039/ c0sm00800a.

Peltzer, M. A., Salvay, A. G., Delgado, J. F., de la Osa, O., \& Wagner, J. R. (2018). Use of residual yeast cell wall for new biobased materials production: Effect of plasticization on film properties. Food and Bioprocess Technology, 11(11), 1995-2007. https://doi. org/10.1007/s11947-018-2156-8.

Pereira, R. N., Rodrigues, R. M., Ramos, Ó. L., Pinheiro, A. C., Martins, J. T., Teixeira, J. A., \& Vicente, A. A. (2018). Electric field processing: Novel perspectives on allergenicity of milk proteins. Journal of Agricultural and Food Chemistry, 66, 11227-11233. https://doi.org/10.1021/acs.jafc.8b03689.

Pereira, R. N., Rodrigues, R. M., Ramos, Ó. L., Xavier Malcata, F., Teixeira, J. A., \& Vicente, A. A. (2016). Production of whey protein-based aggregates under ohmic heating. Food and Bioprocess Technology, 9(4), 576-587. https://doi.org/10.1007/ s11947-015-1651-4.

Pereira, R. N., Teixeira, J. A., \& Vicente, A. A. (2011). Exploring the denaturation of whey proteins upon application of moderate electric fields: A kinetic and thermodynamic study. Journal of Agricultural and Food Chemistry, 59, 11589-11597. https://doi.org/ $10.1021 /$ jf201727s.

Pereira, R. N., \& Vicente, A. A. (2010). Environmental impact of novel thermal and nonthermal technologies in food processing. Food Research International, 43(7), 1936-1943. https://doi.org/10.1016/j.foodres.2009.09.013.

Picariello, G., Ferranti, P., Fierro, O., Mamone, G., Caira, S., Di Luccia, A., ... Addeo, F. (2010). Peptides surviving the simulated gastrointestinal digestion of milk proteins: Biological and toxicological implications. Journal of Chromatography B, 878(3-4), 295-308. https://doi.org/10.1016/j.jchromb.2009.11.033.

Pierucci, A. P. T. R., Andrade, L. R., Baptista, E. B., Volpato, N. M., \& Rocha-Leão, M. H. M. (2006). New microencapsulation system for ascorbic acid using pea protein concentrate as coat protector. Journal of Microencapsulation, 23(6), 654-662. https:// doi.org/10.1080/02652040600776523.

Pierucci, A. P. T. R., Andrade, L. R., Farina, M., Pedrosa, C., \& Rocha-Leão, M. H. M. (2007). Comparison of $\alpha$-tocopherol microparticles produced with different wall materials: Pea protein a new interesting alternative. Journal of Microencapsulation, 24(3), 201-213. https://doi.org/10.1080/02652040701281167.

Pietrzak, W., \& Kawa-Rygielska, J. (2013). Utilization of spent brewer's yeast for supplementation of distillery corn mashes. Polish Journal of Chemical Technology, 15(4), 102-106. https://doi.org/10.2478/pjct-2013-0076. 
Piha, S., Pohjanheimo, T., Lähteenmäki-Uutela, A., Křečková, Z., \& Otterbring, T. (2018). The effects of consumer knowledge on the willingness to buy insect food: An exploratory cross-regional study in northern and Central Europe. Food Quality and Preference, 70, 1-10. https://doi.org/10.1016/j.foodqual.2016.12.006.

Pisoschi, A. M., Pop, A., Cimpeanu, C., Turcuş, V., Predoi, G., \& Iordache, F. (2018). Nanoencapsulation techniques for compounds and products with antioxidant and antimicrobial activity - A critical view. European Journal of Medicinal Chemistry, 157, 1326-1345. https://doi.org/10.1016/j.ejmech.2018.08.076.

Pohlit, H., Bellinghausen, I., Schömer, M., Heydenreich, B., Saloga, J., \& Frey, H. (2015). Biodegradable $\mathrm{pH}$-sensitive poly(ethylene glycol) nanocarriers for allergen encapsulation and controlled release. Biomacromolecules, 16(10), 3103-3111. https:// doi.org/10.1021/acs.biomac.5b00458.

Pojić, M., Mišan, A., \& Tiwari, B. (2018). Eco-innovative technologies for extraction of proteins for human consumption from renewable protein sources of plant origin. Trends in Food Science \& Technology, 75, 93-104. https://doi.org/10.1016/j.tifs.2018. 03.010.

Poma, G., Cuykx, M., Amato, E., Calaprice, C., Focant, J. F., \& Covaci, A. (2017). Evaluation of hazardous chemicals in edible insects and insect-based food intended for human consumption. Food and Chemical Toxicology, 100, 70-79. https://doi.org/ 10.1016/j.fct.2016.12.006.

Premkumar, J., \& Vasudevan, R. T. (2018). Bioingredients: Functional properties and health impacts. Current Opinion in Food Science, 19, 120-128. https://doi.org/10. 1016/j.cofs.2018.03.016.

Puértolas, E., Luengo, E., Álvarez, I., \& Raso, J. (2012). Improving mass transfer to soften tissues by pulsed electric fields: Fundamentals and applications. Annual Review of Food Science and Technology, 3(1), 263-282. https://doi.org/10.1146/annurev-food022811-101208.

Rahaman, T., Vasiljevic, T., \& Ramchandran, L. (2016). Effect of processing on conformational changes of food proteins related to allergenicity. Trends in Food Science \& Technology, 49, 24-34. https://doi.org/10.1016/j.tifs.2016.01.001.

Rahmati, N. F., Koocheki, A., Varidi, M., \& Kadkhodaee, R. (2018). Introducing speckled sugar bean (Phaseolus vulgaris) protein isolates as a new source of emulsifying agent. Food Hydrocolloids, 79, 498-508. https://doi.org/10.1016/j.foodhyd.2018.01.022.

Ramos, O. L., Pereira, R. N., Martins, A., Rodrigues, R., Fuciños, C., Teixeira, J. A., .. Vicente, A. A. (2017). Design of whey protein nanostructures for incorporation and release of nutraceutical compounds in food. Critical Reviews in Food Science and Nutrition, 57(7), 1377-1393. https://doi.org/10.1080/10408398.2014.993749.

Ramos, O. L., Pereira, R. N., Simões, L. S., Madalena, D. A., Rodrigues, R. M., Teixeira, J. A., \& Vicente, A. A. (2019). Nanostructures of whey proteins for encapsulation of food ingredients. In S. M. Jafari (Ed.). Biopolymer nanostructures for food encapsulation purposes (pp. 69-100). . https://doi.org/10.1016/B978-0-12-815663-6.00003-3.

Ramos-Elorduy, J., Moreno, J. M. P., Prado, E. E., Perez, M. A., Otero, J. L., \& de Guevara, O. L. (1997). Nutritional value of edible insects from the state of Oaxaca, Mexico. Journal of Food Composition and Analysis, 10(2), 142-157. https://doi.org/10.1006/ jfca.1997.0530.

Raso, J., Frey, W., Ferrari, G., Pataro, G., Knorr, D., Teissie, J., \& Miklavčič, D. (2016) Recommendations guidelines on the key information to be reported in studies of application of PEF technology in food and biotechnological processes. Innovative Food Science \& Emerging Technologies, 37, 312-321. https://doi.org/10.1016/j.ifset.2016. 08.003 .

Rasouli, Z., Valverde-Pérez, B., D'Este, M., De Francisci, D., \& Angelidaki, I. (2018). Nutrient recovery from industrial wastewater as single cell protein by a co-culture of green microalgae and methanotrophs. Biochemical Engineering Journal, 134, 129-135. https://doi.org/10.1016/j.bej.2018.03.010.

Rastogi, N. K., Raghavarao, K. S. M. S., Balasubramaniam, V. M., Niranjan, K., \& Knorr, D. (2007). Opportunities and challenges in high pressure processing of foods. Critical Reviews in Food Science and Nutrition, 47(1), 69-112. https://doi.org/10.1080/ 10408390600626420

Rayaprolu, S. J., Hettiarachchy, N. S., Horax, R., Kumar-Phillips, G., Liyanage, R., Lay, J., \& Chen, P. (2017). Purification and characterization of a peptide from soybean with cancer cell proliferation inhibition. Journal of Food Biochemistry, 41(4), e12374. https://doi.org/10.1111/jfbc.12374.

Rehman, A., Ahmad, T., Aadil, R. M., Spotti, M. J., Bakry, A. M., Khan, I. M., ... Tong, Q. (2019). Pectin polymers as wall materials for the nano-encapsulation of bioactive compounds. Trends in Food Science \& Technology, 90, 35-46. https://doi.org/10. 1016/j.tifs.2019.05.015.

Reihani, S. F. S., \& Khosravi-Darani, K. (2019). Influencing factors on single-cell protein production by submerged fermentation: A review. Electronic Journal of Biotechnology, 37, 34-40. https://doi.org/10.1016/j.ejbt.2018.11.005.

Reitsma, M., Westerhout, J., Wichers, H. J., Wortelboer, H. M., \& Verhoeckx, K. C. M. (2014). Protein transport across the small intestine in food allergy. Molecular Nutrition \& Food Research, 58(1), 194-205. https://doi.org/10.1002/mnfr.201300204.

Ribeiro, I. C., Leclercq, C. C., Simões, N., Toureiro, A., Duarte, I., Freire, J. B., ... Pinheiro, C. (2017). Identification of chickpea seed proteins resistant to simulated in vitro human digestion. Journal of Proteomics, 169, 143-152. https://doi.org/10.1016/j. jprot.2017.06.009.

Ritala, A., Häkkinen, S. T., Toivari, M., \& Wiebe, M. G. (2017). Single cell protein-Stateof-the-art, industrial landscape and patents 2001-2016. Frontiers in Microbiology, 8. https://doi.org/10.3389/fmicb.2017.02009 (OCT).

Rocha, C. M. R., Genisheva, Z., Ferreira-Santos, P., Rodrigues, R., Vicente, A. A., Teixeira, J. A., \& Pereira, R. N. (2018). Electric field-based technologies for valorization of bioresources. Bioresource Technology, 254, 325-339. https://doi.org/10.1016/j. biortech.2018.01.068.

Rodrigues, R. M., Vicente, A. A., Petersen, S. B., \& Pereira, R. N. (2019). Electric field effects on $\beta$-lactoglobulin thermal unfolding as a function of $\mathrm{pH}$ - Impact on protein functionality. Innovative Food Science \& Emerging Technologies, 52, 1-7. https://doi. org/10.1016/j.ifset.2018.11.010.

Roncolini, A., Milanović, V., Cardinali, F., Osimani, A., Garofalo, C., Sabbatini, R., .. Aquilanti, L. (2019). Protein fortification with mealworm (Tenebrio molitor L.) powder: Effect on textural, microbiological, nutritional and sensory features of bread.
PLoS One, 14(2), e0211747. https://doi.org/10.1371/journal.pone.0211747.

Roos, N. (2018). Insects and human nutrition. In A. Halloran, R. Flore, N. Roos, \& P. Vantomme (Eds.). Edible insects in sustainable food systems (pp. 83-91). Cham: Springer International Publishing.

Rubio, L. A., Grant, G., Caballé, C., Martinez-Aragón, A., \& Pusztai, A. (1994). High invivo (rat) digestibility of faba bean (Vicia faba), lupin (Lupinus angustifolius) and soya bean (Glycine max) soluble globulins. Journal of the Science of Food and Agriculture, 66(3), 289-292. https://doi.org/10.1002/jsfa.2740660305.

Ruiz, G. A., Xiao, W., van Boekel, M., Minor, M., \& Stieger, M. (2016). Effect of extraction $\mathrm{pH}$ on heat-induced aggregation, gelation and microstructure of protein isolate from quinoa (Chenopodium quinoa Willd). Food Chemistry, 209, 203-210. https://doi.org/ 10.1016/j.foodchem.2016.04.052.

Saejung, C., \& Salasook, P. (2018). Recycling of sugar industry wastewater for single-cell protein production with supplemental carotenoids. Environmental Technology, 3330, 1-12. https://doi.org/10.1080/09593330.2018.1491633.

Safi, C., Ursu, A. V., Laroche, C., Zebib, B., Merah, O., Pontalier, P.-Y., \& Vaca-Garcia, C (2014). Aqueous extraction of proteins from microalgae: Effect of different cell disruption methods. Algal Research, 3(1), 61-65. https://doi.org/10.1016/j.algal.2013. 12.004.

Samaranayake, C. P., \& Sastry, S. K. (2016a). Effect of moderate electric fields on inactivation kinetics of pectin methylesterase in tomatoes: The roles of electric field strength and temperature. Journal of Food Engineering, 186, 17-26. https://doi.org/ 10.1016/j.jfoodeng.2016.04.006.

Samaranayake, C. P., \& Sastry, S. K. (2016b). Effects of controlled-frequency moderate electric fields on pectin methylesterase and polygalacturonase activities in tomato homogenate. Food Chemistry, 199, 265-272. https://doi.org/10.1016/j.foodchem. 2015.12.010

Samaranayake, C. P., \& Sastry, S. K. (2018). In-situ activity of $\alpha$-amylase in the presence of controlled-frequency moderate electric fields. LWT, 90, 448-454. https://doi.org/ 10.1016/j.lwt.2017.12.053.

Sastry, S. K. (2014). Overview of ohmic heating. In M. M. H. S. Ramaswamy Sudhir Sastry, \& K. Abdelrahim (Eds.). Ohmic heating in food processingCRC Press (CRC Press).

Sceni, P., Palazolo, G. G., del Carmen Vasallo, M., Puppo, M. C., Otero, M. A., \& Wagner, J. R. (2009). Thermal and surface behavior of yeast protein fractions from Saccharomyces cerevisiae. LWT - Food Science and Technology, 42(6), 1098-1106. https://doi.org/10.1016/j.lwt.2009.02.010.

Schwenzfeier, A., Helbig, A., Wierenga, P. A., \& Gruppen, H. (2013). Emulsion properties of algae soluble protein isolate from Tetraselmis sp. Food Hydrocolloids, 30(1), 258-263. https://doi.org/10.1016/j.foodhyd.2012.06.002

Schwenzfeier, A., Wierenga, P. A., \& Gruppen, H. (2011). Isolation and characterization of soluble protein from the green microalgae Tetraselmis sp. Bioresource Technology, 102(19), 9121-9127. https://doi.org/10.1016/j.biortech.2011.07.046.

Sen, M., Kopper, R., Pons, L., Abraham, E. C., Burks, A. W., \& Bannon, G. A. (2002). Protein structure plays a critical role in peanut allergen stability and may determine immunodominant IgE-binding epitopes. The Journal of Immunology, 169(2), 882-887. https://doi.org/10.4049/jimmunol.169.2.882.

Shi, X., Zou, H., Sun, S., Lu, Z., Zhang, T., Gao, J., \& Yu, C. (2019). Application of high pressure homogenization for improving the physicochemical, functional and rheological properties of myofibrillar protein. International Journal of Biological Macromolecules. https://doi.org/10.1016/j.ijbiomac.2019.07.110 (In Press).

Shih, M. F., \& Cherng, J. Y. (2012). Protective effects of chlorella-derived peptide against UVC-induced cytotoxicity through inhibition of caspase-3 activity and reduction of the expression of phosphorylated FADD and cleaved PARP-1 in skin fibroblasts. Molecules, 17(8), 9116-9128. https://doi.org/10.3390/molecules17089116.

da Silva Santos, V., Badan Ribeiro, A. P., \& Andrade Santana, M. H. (2019). Solid lipid nanoparticles as carriers for lipophilic compounds for applications in foods. Food Research International, 122, 610-626. https://doi.org/10.1016/j.foodres.2019.01. 032.

Smetana, S., Palanisamy, M., Mathys, A., \& Heinz, V. (2016). Sustainability of insect use for feed and food: Life cycle assessment perspective. Journal of Cleaner Production, 137, 741-751. https://doi.org/10.1016/j.jclepro.2016.07.148

Song, M., Fung, T. T., Hu, F. B., Willett, W. C., Longo, V. D., Chan, A. T., \& Giovannucci, E. L. (2016). Association of animal and plant protein intake with all-cause and causespecific mortality. JAMA Internal Medicine, 176(10), 1453. https://doi.org/10.1001/ jamainternmed.2016.4182.

Sosa, D. A. T., \& Fogliano, V. (2017). Potential of insect-derived ingredients for food applications. In InTech (Ed.). Insect physiology and ecology (pp. 215-231). . https:// doi.org/10.5772/67318.

de Souza Simões, L., Madalena, D. A., Pinheiro, A. C., Teixeira, J. A., Vicente, A. A., \& Ramos, Ó. L. (2017). Micro- and nano bio-based delivery systems for food applications: In vitro behavior. Advances in Colloid and Interface Science, 243, 23-45. https:// doi.org/10.1016/j.cis.2017.02.010.

van der Spiegel, M., Noordam, M. Y., \& van der Fels-Klerx, H. J. (2013). Safety of novel protein sources (insects, microalgae, seaweed, duckweed, and rapeseed) and legislative aspects for their application in food and feed production. Comprehensive Reviews in Food Science and Food Safety, 12(6), 662-678. https://doi.org/10.1111/ 1541-4337.12032.

Stoll-Kleemann, S., \& Schmidt, U. J. (2017). Reducing meat consumption in developed and transition countries to counter climate change and biodiversity loss: A review of influence factors. Regional Environmental Change, 17(5), 1261-1277. https://doi.org/ 10.1007/s10113-016-1057-5.

Stone, A. K., Karalash, A., Tyler, R. T., Warkentin, T. D., \& Nickerson, M. T. (2015) Functional attributes of pea protein isolates prepared using different extraction methods and cultivars. Food Research International, 76, 31-38. https://doi.org/10. 1016/j.foodres.2014.11.017.

Stull, V. J., Finer, E., Bergmans, R. S., Febvre, H. P., Longhurst, C., Manter, D. K., ... Weir, T. L. (2018). Impact of edible cricket consumption on gut microbiota in healthy adults, a double-blind, randomized crossover trial. Scientific Reports, 8(1), 10762. https://doi.org/10.1038/s41598-018-29032-2.

Sui, Y., Muys, M., Vermeir, P., D'Adamo, S., \& Vlaeminck, S. E. (2019). Light regime and 
growth phase affect the microalgal production of protein quantity and quality with Dunaliella salina. Bioresource Technology, 275, 145-152. https://doi.org/10.1016/j. biortech.2018.12.046.

Sun-Waterhouse, D., Waterhouse, G. I. N., You, L., Zhang, J., Liu, Y., Ma, L., ... Dong, Y. (2016). Transforming insect biomass into consumer wellness foods: A review. Food Research International, 89, 129-151. https://doi.org/10.1016/j.foodres.2016.10.001.

Tabilo-Munizaga, G, Villalobos-Carvajal, R, Herrera-Lavados, C., Moreno-Osorio, L, Jarpa-Parra, M., \& Pérez-Won, M. (2019). Physicochemical properties of high-pressure treated lentil protein-based nanoemulsions. LWT, 101, 590-598. https://doi. org/10.1016/j.lwt.2018.11.070.

Tabtabaei, S., Konakbayeva, D., Rajabzadeh, A. R., \& Legge, R. L. (2019). Functional properties of navy bean (Phaseolus vulgaris) protein concentrates obtained by pneumatic tribo-electrostatic separation. Food Chemistry, 283, 101-110. https://doi. org/10.1016/j.foodchem.2019.01.031.

Tamayo Tenorio, A., Gieteling, J., Nikiforidis, C. V., Boom, R. M., \& van der Goot, A. J. (2017). Interfacial properties of green leaf cellulosic particles. Food Hydrocolloids, 71, 8-16. https://doi.org/10.1016/j.foodhyd.2017.04.030.

Tarhini, M., Greige-Gerges, H., \& Elaissari, A. (2017). Protein-based nanoparticles: From preparation to encapsulation of active molecules. International Journal of Pharmaceutics, 522(1-2), 172-197. https://doi.org/10.1016/j.ijpharm.2017.01.067.

Taylor, S. L., \& Hefle, S. L. (2001). Food allergies and other food sensitivities. Food Technology, 55(9), 68-83.

Tharrey, M., Mariotti, F., Mashchak, A., Barbillon, P., Delattre, M., \& Fraser, G. E. (2018). Patterns of plant and animal protein intake are strongly associated with cardiovascular mortality: The Adventist health Study-2 cohort. International Journal of Epidemiology, 47(5), 1603-1612. https://doi.org/10.1093/ije/dyy030.

Tian, J.(. J.)., Bryksa, B. C., \& Yada, R. Y. (2016). Feeding the world into the future - Food and nutrition security: The role of food science and technology $\uparrow$. Frontiers in Life Science, 9(3), 155-166. https://doi.org/10.1080/21553769.2016.1174958.

Timmermans, R. A. H., Mastwijk, H. C., Berendsen, L. B. J. M., Nederhoff, A. L., Matser, A. M., Van Boekel, M. A. J. S., \& Nierop Groot, M. N. (2019). Moderate intensity pulsed electric fields (PEF) as alternative mild preservation technology for fruit juice. International Journal of Food Microbiology, 298, 63-73. https://doi.org/10.1016/j. ijfoodmicro.2019.02.015.

Turck, D., Castenmiller, J., de Henauw, S., Hirsch-Ernst, K., Kearney, J., Maciuk, A., .. Knutsen, H. K. (2019). Safety of Yarrowia lipolytica yeast biomass as a novel food pursuant to regulation (EU) 2015/2283. EFSA Journal, 17(2), https://doi.org/10. 2903/j.efsa.2019.5594.

Ukaegbu-obi, K. (2016). Single cell protein: A resort to global protein challenge and waste management. Journal of Microbiology \& Microbial Technology, 1(1), 5. https://doi.org/ 10.13188/2474-4530.1000006.

Untersmayr, E., \& Jensen-Jarolim, E. (2008). The role of protein digestibility and antacids on food allergy outcomes. Journal of Allergy and Clinical Immunology, 121(6), 1301-1308. https://doi.org/10.1016/j.jaci.2008.04.025.

Ursu, A.-V., Marcati, A., Sayd, T., Sante-Lhoutellier, V., Djelveh, G., \& Michaud, P. (2014). Extraction, fractionation and functional properties of proteins from the microalgae Chlorella vulgaris. Bioresource Technology, 157, 134-139. https://doi.org/10.1016/j. biortech.2014.01.071.

Valenta, R., Hochwallner, H., Linhart, B., \& Pahr, S. (2015). Food allergies: The basics. Gastroenterology, 148(6), 1120-1131. (e4) https://doi.org/10.1053/j.gastro.2015.02. 006.

Verdugo, M., Lim, L.-T., \& Rubilar, M. (2014). Electrospun protein concentrate fibers from microalgae residual biomass. Journal of Polymers and the Environment, 22(3), 373-383. https://doi.org/10.1007/s10924-014-0678-3.

Verhoeckx, K., Bøgh, K. L., Dupont, D., Egger, L., Gadermaier, G., Larré, C., ... Epstein, M. M. (2019). The relevance of a digestibility evaluation in the allergenicity risk assessment of novel proteins. Opinion of a joint initiative of COST action ImpARAS and COST action INFOGEST. Food and Chemical Toxicology, 129, 405-423. https://doi. org/10.1016/j.fct.2019.04.052

Verhoeckx, K., Broekman, H., Knulst, A., \& Houben, G. (2016). Allergenicity assessment strategy for novel food proteins and protein sources. Regulatory Toxicology and Pharmacology, 79, 118-124. https://doi.org/10.1016/j.yrtph.2016.03.016.

Verhoeckx, K. C. M., Vissers, Y. M., Baumert, J. L., Faludi, R., Feys, M., Flanagan, S., ... Kimber, I. (2015). Food processing and allergenicity. Food and Chemical Toxicology, 80, 223-240. https://doi.org/10.1016/j.fct.2015.03.005.

Vieira, E., Cunha, S. C., \& Ferreira, I. M. P. L. V. O (2018). Characterization of a potential bioactive food ingredient from inner cellular content of Brewer's spent yeast. Waste and Biomass Valorization. https://doi.org/10.1007/s12649-018-0368-9.

Vieira, E. F., da Silva, D. D., Carmo, H., \& Ferreira, I. M. P. L. V. O. (2017). Protective ability against oxidative stress of brewers' spent grain protein hydrolysates. Food Chemistry, 228, 602-609. https://doi.org/10.1016/j.foodchem.2017.02.050.

Vos, R., \& Bellù, L. G. (2019). Global trends and challenges to food and agriculture into the 21st century. In C. Campanhola, \& S. Pandey (Eds.). Sustainable food and agriculture (pp. 11-30). . https://doi.org/10.1016/B978-0-12-812134-4.00002-9.

Waghmare, A. G., Salve, M. K., LeBlanc, J. G., \& Arya, S. S. (2016). Concentration and characterization of microalgae proteins from Chlorella pyrenoidosa. Bioresources and Bioprocessing, 3(1), 16. https://doi.org/10.1186/s40643-016-0094-8.

Wallecan, J., McCrae, C., Debon, S. J. J., Dong, J., \& Mazoyer, J. (2015). Emulsifying and stabilizing properties of functionalized orange pulp fibers. Food Hydrocolloids, 47, 115-123. https://doi.org/10.1016/j.foodhyd.2015.01.009.

Wang, H., She, Y., Chu, C., Liu, H., Jiang, S., Sun, M., \& Jiang, S. (2015). Preparation, antimicrobial and release behaviors of nisin-poly (vinyl alcohol)/wheat gluten/ZrO2 nanofibrous membranes. Journal of Materials Science, 50(14), 5068-5078. https:// doi.org/10.1007/s10853-015-9059-0.

Wang, J. P., Kim, J. D., Kim, J. E., \& Kim, I. H. (2013). Amino acid digestibility of single cell protein from Corynebacterium ammoniagenes in growing pigs. Animal Feed Science and Technology, 180(1-4), 111-114. https://doi.org/10.1016/j.anifeedsci. 2012.12.006.

Wang, Y., Ghosh, S., \& Nickerson, M. T. (2019). Effect of pH on the formation of electrostatic complexes between lentil protein isolate and a range of anionic polysaccharides, and their resulting emulsifying properties. Food Chemistry, 298, 125023 https://doi.org/10.1016/j.foodchem.2019.125023.

Woolf, E., Zhu, Y., Emory, K., Zhao, J., \& Liu, C. (2019). Willingness to consume insectcontaining foods: A survey in the United States. LWT, 102, 100-105. https://doi.org/ 10.1016/j.lwt.2018.12.010.

Worldometers (2019). From 1950 to current year: Elaboration of data by United Nations, Department of Economic and Social Affairs, population division. World population prospects: The 2017 revision (Medium-fertility variant). Retrieved March 5, 2019 , from http://www.worldometers.info/world-population/world-populationprojections.

Wu, W., Kong, X., Zhang, C., Hua, Y., \& Chen, Y. (2018). Improving the stability of wheat gliadin nanoparticles - Effect of gum arabic addition. Food Hydrocolloids, 80, 78-87. https://doi.org/10.1016/j.foodhyd.2018.01.042.

Wu, Y., Luo, Y., \& Wang, Q. (2012). Antioxidant and antimicrobial properties of essential oils encapsulated in zein nanoparticles prepared by liquid-liquid dispersion method. LWT - Food Science and Technology, 48(2), 283-290. https://doi.org/10.1016/j.lwt. 2012.03.027.

Yan, J., Han, B., Gui, X., Wang, G., Xu, L., Yan, Y., ... Jiao, L. (2018). Engineering Yarrowia lipolytica to simultaneously produce lipase and single cell protein from agro-industrial wastes for feed. Scientific Reports, 8(1), 758. https://doi.org/10.1038/ s41598-018-19238-9.

Yang, A., Zhang, G., Meng, F., Lu, P., Wang, X., \& Peng, M. (2017). Enhancing protein to extremely high content in photosynthetic bacteria during biogas slurry treatment. Bioresource Technology, 245, 1277-1281. https://doi.org/10.1016/j.biortech.2017. 08.109.

Yang, R., Liu, Y., Gao, Y., Yang, Z., Zhao, S., Wang, Y., ... Zhou, Z. (2018). Nano-encapsulation of epigallocatechin gallate in the ferritin-chitosan double shells: Simulated digestion and absorption evaluation. Food Research International, 108, 1-7. https://doi.org/10.1016/j.foodres.2018.02.074.

Yi, L., Lakemond, C. M. M., Sagis, L. M. C., Eisner-Schadler, V., van Huis, A., \& van Boekel, M. A. J. S. (2013). Extraction and characterisation of protein fractions from five insect species. Food Chemistry, 141(4), 3341-3348. https://doi.org/10.1016/j foodchem.2013.05.115.

Zang, X., Yue, C., Liu, M., Zheng, H., Xia, X., \& Yu, G. (2019). Improvement of freeze-thaw stability of oil-in-water emulsions prepared with modified soy protein isolates. $L W T$ 102, 122-130. https://doi.org/10.1016/j.lwt.2018.09.004.

Zepka, L. Q., Jacob-Lopes, E., Goldbeck, R., Souza-Soares, L. A., \& Queiroz, M. I. (2010). Nutritional evaluation of single-cell protein produced by Aphanothece microscopica Nägeli. Bioresource Technology, 101(18), 7107-7111. https://doi.org/10.1016/j. biortech.2010.04.001.

Zhao, X., Vázquez-Gutiérrez, J. L., Johansson, D. P., Landberg, R., \& Langton, M. (2016). Yellow mealworm protein for food purposes - extraction and functional properties. PLoS One, 11(2), e0147791. https://doi.org/10.1371/journal.pone.0147791.

Zielińska, E., Baraniak, B., Karaś, M., Rybczyńska, K., \& Jakubczyk, A. (2015). Selected species of edible insects as a source of nutrient composition. Food Research International. https://doi.org/10.1016/j.foodres.2015.09.008.

Zielińska, E., Karaś, M., \& Baraniak, B. (2018). Comparison of functional properties of edible insects and protein preparations thereof. $L W T, 91,168-174$. https://doi.org/ 10.1016/j.lwt.2018.01.058.

Zimmermann, C., Eaton, A. D., Lanter, B. B., Roper, J., Hurley, B. P., \& Delaney, B. (2018). Extended exposure duration of cultured intestinal epithelial cell monolayers in characterizing hazardous and non-hazardous proteins. Food and Chemical Toxicology, 115, 451-459. https://doi.org/10.1016/j.fct.2018.03.047. 